Bryn Mawr College

Scholarship, Research, and Creative Work at Bryn Mawr College

Classical and Near Eastern Archaeology Faculty

Research and Scholarship

Classical and Near Eastern Archaeology

1994

\title{
The Mycenaean Entrance System at the West End of the Akropolis of Athens
}

James C. Wright

Bryn Mawr College, jwright@brynmawr.edu

Let us know how access to this document benefits you.

Follow this and additional works at: http://repository.brynmawr.edu/arch_pubs

Part of the Classical Archaeology and Art History Commons, and the History of Art, Architecture, and Archaeology Commons

\section{Custom Citation}

Wright, James C. 1994. The Mycenaean Entrance System at the West End of the Akropolis of Athens. Hesperia 63:323-360.

This paper is posted at Scholarship, Research, and Creative Work at Bryn Mawr College. http://repository.brynmawr.edu/arch_pubs/90

For more information, please contact repository@brynmawr.edu. 


\section{THE MYCENAEAN ENTRANCE SYSTEM AT THE WEST END OF THE AKROPOLIS OF ATHENS}

(Plates 77-80)

In memory of William B. Dinsmoor, Jr.

TNTEREST in the form of the defenses of the Akropolis during the Mycenaean period I is not merely a concern of archaeologists of the Late Bronze Age of Greece. It is widely accepted that for the most part these fortifications remained in use through the Persian War. Thus their original state and evidence for any early alterations have direct bearing on historic Athens. This has recently been emphasized in the study of the remains of the predecessors of the Propylaia published by William B. Dinsmoor, Jr. It is also one of the central issues in a study of the Sanctuary of Athena Nike by Ira Mark, who has provided much new information pertinent to the research published here, and it is once again discussed in a reevaluation of the remains of the Older Propylon by Harrison Eiteljorg II. ${ }^{1}$

The purpose of this study is to present a clear and complete discussion of the evidence for the Mycenaean entrance system at the western end of the Akropolis. Recent research has run counter to the conclusions of the only comprehensive examination of the Mycenaean Akropolis, the 1963 dissertation of Spyros Iakovides, and there is no recent detailed actualstate plan of the western slope of the Akropolis that could serve as an established point of reference. Researches in this area extend back to the time of Ludwig Ross and his colleagues, and therefore it is useful to begin with a brief survey of the history of scholarship on this problem, focusing primarily on those who made discoveries relevant to it. This allows some winnowing of the evidence and results in a new appraisal that I argue gives a more

1 The research for this paper was conducted between 1976 and 1983; funding for the drawings and for study of the remains in situ was provided by a Grant-in-Aid for Recent Ph.D. Recipients from the American Council of Learned Societies (1979). A Europa-stipendium from the Alexander von Humboldt Foundation in 1983 allowed me to continue my studies on the Akropolis. For permissions to study these remains, I thank Professor George Dontas and Dr. Evi Stasinopoulou-Touloupa, successive Ephors of the Akropolis. I am grateful to Professor Henry Immerwahr, former Director of the American School of Classical Studies at Athens, for assistance and encouragement. Dr. Judith Binder has been a continuing inspiration for this study, and I am grateful for her guidance and patience. I thank Professor Bernard Andreae for his generosity in sponsoring my research in Germany. Professors Heinrich Drerup and Bernhard Schmaltz provided stimulating discussion and offered comments on the work that appears in the Appendix. Ira Mark, Harrison Eiteljorg, and I have often discussed the problem of the form of the Mycenaean entrance system. I am grateful to Professor Mark for sharing the results of his researches and, while a visiting colleague in my department during the academic year 1989-1990, stimulating me to bring my work to conclusion. He is, along with those others who have helped me, in no way responsible for any errors of fact or for any of the interpretations which I offer in this paper. I dedicate this work to William B. Dinsmoor, Jr., who provided much information from his archives, drew many of the figures, and urged me to complete this study as a complement to his own observations published in his study of the predecessors of the Propylaia. Eiteljorg's study (in press) will appear as the first volume in the monograph series of the Archaeological Institute of America. 


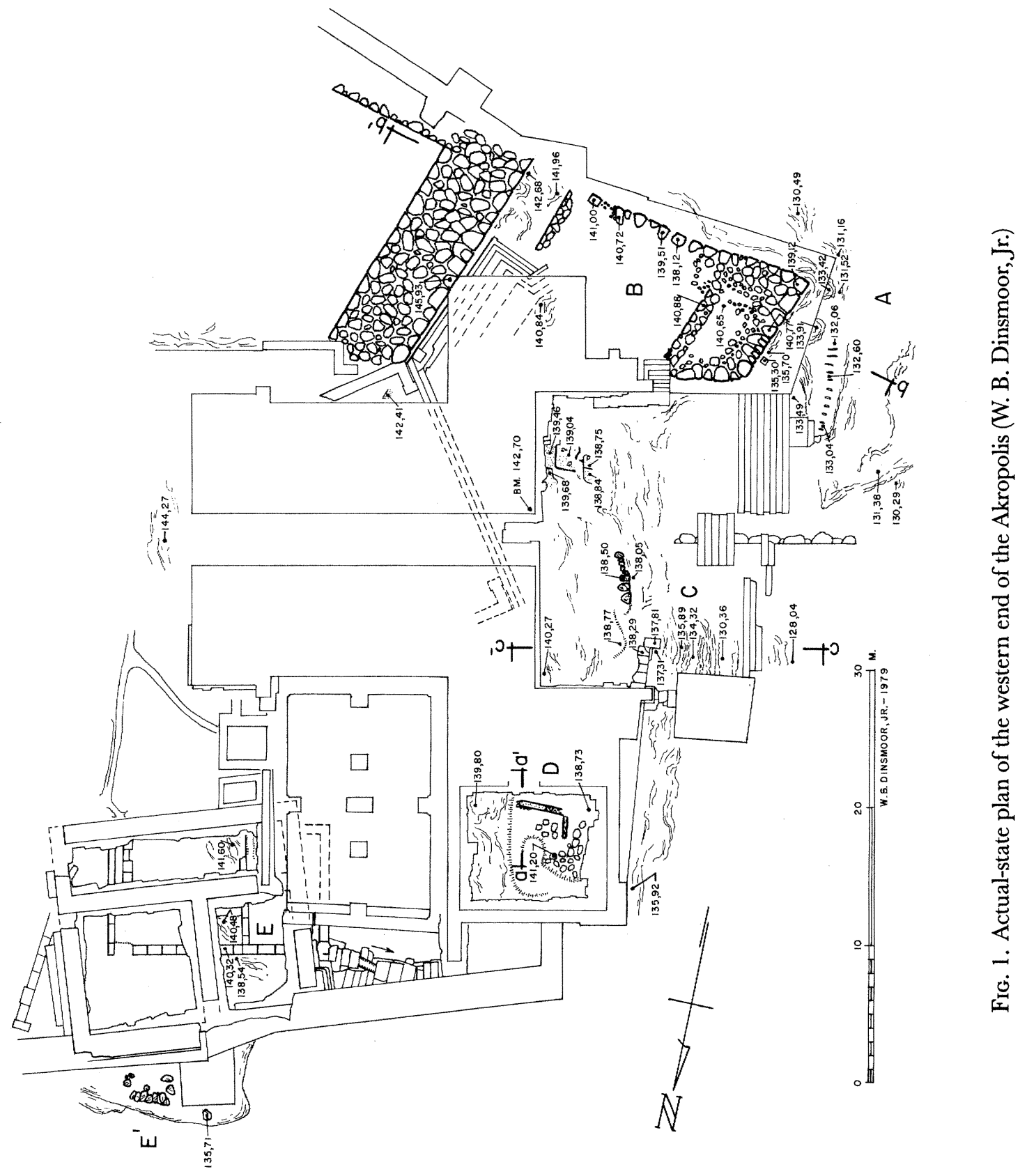


dispassionate view and a more balanced reconstruction of the remains than has been possible in the past.

\section{HISTORY OF INVESTIGATIONS}

The archaeological evidence that has been identified as determining the approach to and configuration of the western entrance to the Akropolis of Athens during the Late Bronze Age is found at seven areas on the western slope of the Akropolis (Fig. 1):

\section{The Approach}

1. A dressed bedrock pathway with a number of nearly parallel bedrock cuttings that extend from the foot of the bastion of the Temple of Athena Nike to beyond its northwest corner (starting at "132.06" on Fig. 1).

\section{The Bastion}

2. The Cyclopean bastion underneath the Temple of Athena Nike and its precinct.

3. A small stretch of polygonal wall due east of the temple and nearly parallel to the West Cyclopean Wall (next to "141.96" on Fig. 1).

\section{The West Cyclopean Wall}

4. The wall extends from the southern cliff northwards to the south wall of the Older Propylon, where it breaks off.

\section{The North Side}

5. A curved line of rubble masonry on the brow of the bedrock in the ramp area directly before the central entrance to the Propylaia (at "138.50" on Fig. 1).

6. A rubble-and-earth fill of Late Helladic date with two associated stubs of wall underneath the floor of the Pinakotheke (at "141.20" on Fig. 1).

7. Various items of evidence for the course of the northern leg of the Cyclopean wall.

Although Ludwig Ross and Eduard Schaubert first cleared the pathway at the base of the Athena Nike bastion in $1834,{ }^{2}$ it was not until 1852, when Charles Beulé conducted researches in this area, that a series of stepped cuttings in the bedrock was discovered. ${ }^{3}$ They had been covered, he reported, by the paving of the pathway of the medieval gate. Underneath, Beule found a small path about a meter wide worn into the bedrock; its approach had four broad irregular cuttings followed by deep, rounded depressions set equidistant from one another. These he attributed to the action of hooved animals over the course of time, which when led up the path had placed one foot, then the other, in the same place until hollows were worn in the rock. ${ }^{4}$ Such holes, he claimed, are remarkably

2 Ross, Schaubert, and Hansen 1839, pp. 1, 7; pls. III, IV. Ross (1861, p. 271) believed the stairway alongside the bastion was Mnesiclean.

3 Beulé 1862, p. 44.

4 Beulé 1862, p. 44: "Il present d'abord quatre entailles irrégulières, des sorts de marches concaves où le pied s'enfonce; puis, disposés à égale distance sur le pente, des trous ronds et profonds que la sabot des 
similar to those often found on mountain paths. The pathway then mounted in the direction of the Agrippa Monument. ${ }^{5}$

Reworking this area in the early 1880's, Richard Bohn claimed that there was a total of eighteen steps, seven more than Beule had discovered. He asserted that the cuttings in the pathway could be followed eastwards directly up to the base of the Roman steps and not to the north as Beule had reported. ${ }^{6}$ Furthermore, Bohn examined the fill over the bedrock and, with H. G. Lolling's advice on the date of the sherds from the fill over the cuttings, argued a Mycenanean date for the pathway. ${ }^{7}$ As yet, however, no other evidence was available concerning the form of the approach and entrance system. With the excavations of Konstantinos Kavvadias between 1885 and 1890, most of the remaining evidence bearing on this problem came to light. ${ }^{8}$ The issue of the steplike cuttings concerned Kavvadias' architect, Georg Kawerau, who, although contradicting Bohn's assertion on the number, was unable to resolve it satisfactorily. ${ }^{9}$

Other Mycenaean material was also uncovered and reported by these investigators, although it was not applied to interpretations of the Mycenaean entrance system for nearly fifty years. The most significant, for this discussion, was a thick deposit of Mycenaean fill underneath the Pinakotheke. The deposit lay over the bedrock; that to the east consisted mostly of soil, that to the west, of limestone blocks. This fill was interpreted to be in part the result of redumped material from the excavation through Mycenaean levels of foundation trenches for the Pinakotheke. That portion lying immediately over the bedrock was undisturbed prehistoric material; the remaining fill contained Mycenaean pottery and "other pieces of pre-Persian date." 10

Even with this new evidence the horizons of the argument were not enlarged. In 1904 Charles Weller published an article on the pre-Periclean Propylon that was the result of remeasurement and excavation around the Propylaia. In the course of his work, he too had worried about the steplike cuttings before the Nike Temple and stated that there was

animaux a lentement creusis, à force de se poser à la même place. Tels sont les trous l'on remarque souvent sur les sentiers de montagnes." See also Michaelis 1876, pp. 276-277.

5 This account was confirmed by Michaelis in 1875 (1876, pp. 276-277, pl. XV). He attempted to show that similar cuttings were visible near the Agrippa Monument and in front of the southern columns of the west façade of the Propylaia so that a winding ascent could be reconstructed. Beulé (1862, pp. 44-45, 68) also believed the route to have followed this line.

6 Bohn 1880, pp. 311-312; 1882, pp. 15-16. These steps had been installed by the architect Desbuisson.

7 Bohn 1880, p. 311 ; 1882, p. 15.

8 Kavvadias and Kawerau 1906, cols. 14, 41-42, 60, 134-140.

9 Like Beulé, Kawerau recorded only eleven. He was unable to observe the steps turning eastwards as Bohn claimed, and he was not impressed by the quality of the evidence ("bestimmtes über diese Wegespuren lässt sich kaum sagen." Kavvadias and Kawerau 1906, cols. 134, 136). Indeed, he cast doubt on the date of the steps by wondering if the cuttings were actually pre-Mnesiclean or "... erst mit dem mittelaltlichen Reitweg in Verbindung zu bringen sind," even though Beulé (note 4 above) explicitly stated that he found the cuttings under the paving of the "medieval" entranceway (see also p. 336 below).

10 Kavvadias and Kawerau 1906, col. 60; the upper fill was backfill from the foundation trenches: "Es war deutlich festzustellen, dass für die Fundamente der Propylaen ringsum einer Baugrube in das bestehende Terrain eingeschnitten wurde, die man nach Fertigstellen des Gebaudes weiderzufülte." See also Wolters 1889, pp. 121-122. 
one more cutting than Bohn had recorded, but otherwise he subscribed to Bohn's view that the steps turned eastwards. ${ }^{11}$

The problem of the western entrance lay dormant until Gabriel Welter issued an interim report in 1939 on the restoration of the Athena Nike Temple by the Department of Restoration under the supervision of Nikolaos Balanos. ${ }^{12}$

Aside from brief notices, this report constituted the only published eyewitness account of these discoveries until Balanos' final report was published in $1956 .{ }^{13}$ Thus it served for a quarter of a century as the principal source of information on the earlier material on the bastion, but it is untrustworthy because of the sketchy nature and unfounded basis of Welter's reconstructed plan (Fig. 2). ${ }^{14}$

Seven years later, Welter's version of the entrance system was modified by Gorham P. Stevens. Stevens' interest in the prehistoric gateway was spurred by his discovery of a curving

11 Weller 1904, pp. 68-69. Weller claims to have made an exceedingly careful study of this area and illustrates twelve cuttings that he asserts confirmed Bohn's work, since they turn to the east. Despite this, Weller's drawing actually contradicts Bohn, for, like Kawerau before him, he was unable to find any trace of the cuttings north of the square blocks set in front of the stairs. Weller said he found the twelfth step jutting out from under those blocks. This appears unlikely since neither Kawerau nor Bohn saw one there, and Beulé, who had the opportunity to study this area before the blocks were set in place by Desbuisson, recorded nothing at this point. The additional cuttings claimed by Bohn would necessarily have lain at a lower level on the northward sloping rock face. A preliminary drawing of Kawerau's, published by Bundgård (1974a, pl. 204:4), shows how the bedrock falls away just after the eleventh step. Curiously, Bohn did not report on the blocks labeled 4, 5, 6, and 7 on Kawerau's plan. Since these were not recorded by Beulé, they would seem to have been added along with other constructions $c a$. 1865 and later. If they postdate Bohn's discoveries, then at least they demonstrate that his extra rock cuttings were not at the same level as the others but instead led down along the steep declivity of the north face. Kawerau also observed that the square platform of blocks (just east of "133.04" on Fig. 1) was added during restoration work after 1865 (Kavvadias and Kawerau 1906, col. 134). This is confirmed by observing Beule's plan, which does not show these blocks (1862, facing p. 42).

12 Walther Judeich had considered the matter in his Topographie von Athen (1931, pp. 214-215), where he discussed the cuttings in conjunction with a hypothetical ascent from the Klepsydra that used cuttings near the Agrippa monument (Welter 1939, cols. 1-9).

13 In addition to Welter's account, informative briefs were published by Paul Lemerle (1936, p. 455, pl. 5; 1937, p. 443, figs. 4-7; 1938, pp. 448-450, figs. 5-7, pl. 50; 1939, p. 289, fig. 3); Blegen (1936, p. 145, figs. 1-4 and 1940, p. 537, fig. 1); Karo (1936, cols. 94-99); Riemann (1937, col. 92); and Walter (1940, cols. 144-152, figs. 18-23).

14 Welter 1939, fig. 4. Welter described the material of the bastion as great blocks of Akropolis limestone and some others from the hill of the Nymphs; between them was earth packing from which were recovered (cols. 5-6) "mittelhelladische Keramik aus Aigina, gleichzeitige Mahlsteine aus Trachyt und einzige spatmykenische (LH III) Scherben." The upper masonry courses were chinked with stone wedges. One further bit of information is supplied (col. 9): directly behind the niche in the west face of the Classical wall is a corresponding one in the "Pelasgian" wall which has a pillar of poros blocks set in its center (Fig. 4).

Welter's interpretation (cols. 7-9) of these remains (Fig. 2) describes a guarded entranceway, the Enneapylon, but there is no evidence for the ramp and outer wall of his restoration. At the top of the ascent, just where the turning point towards the propylon is, Welter restored a hypothetical guardroom set alongside the west Cyclopean wall and having as its western interior face a small stretch of polygonal wall that had been discovered by Bohn and completely cleared and described by Kavvadias and Kawerau (Welter 1939, p. 8, fig. 4; Bohn 1882, pl. II; Kavvadias and Kawerau 1906, col. 140, pl. $\mathrm{H}^{\prime}$ ). Welter does not comment on this wall, but it is clear from the sketch plan (his fig. 4) that he intended the wall examined by Kavvadias and Kawerau. 

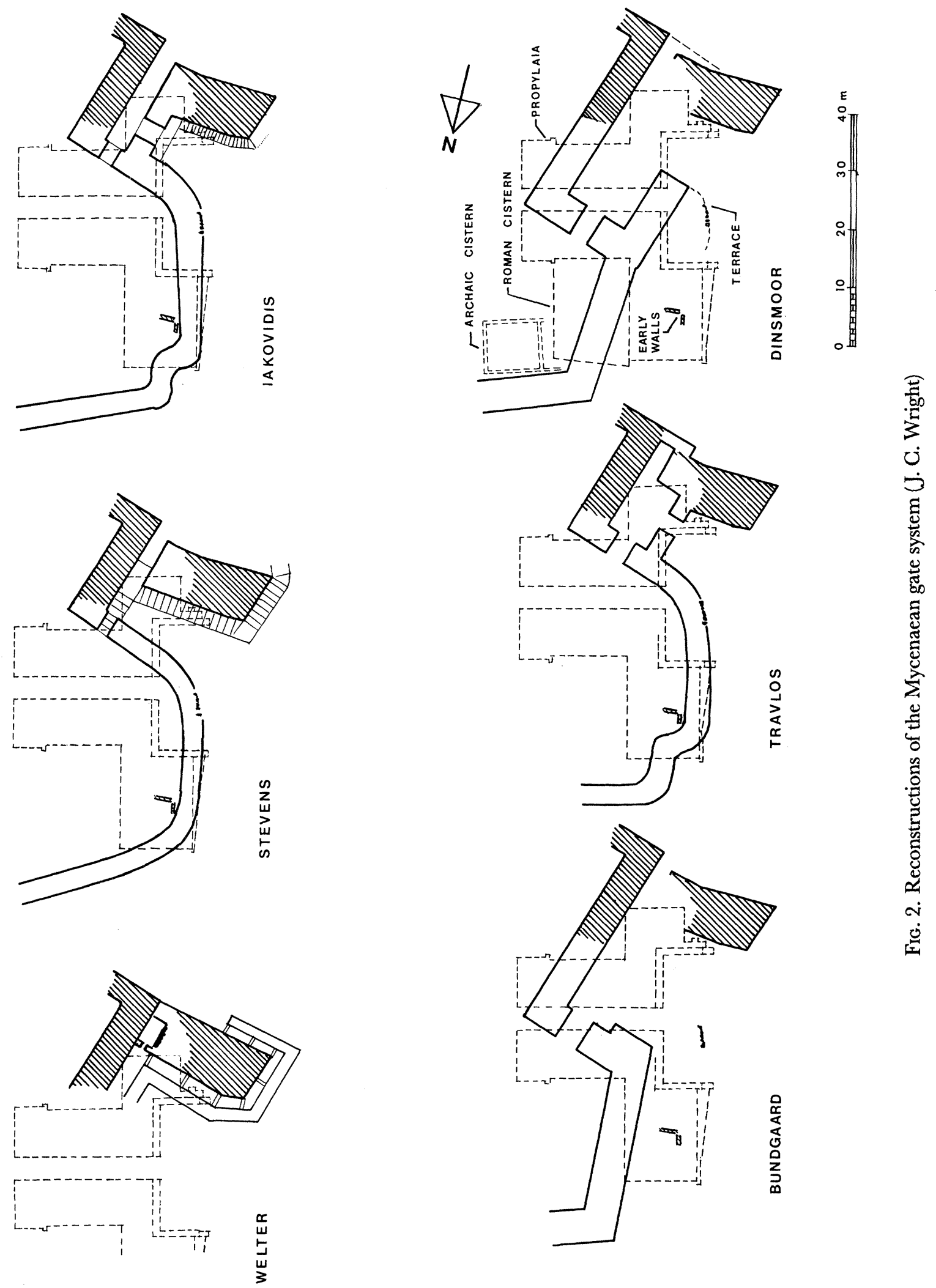

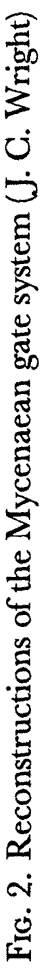


section of rubble wall in the ramp area about seven meters due west of the central entrance of the Propylaia (at "138.50" on Fig. 1). While cleaning around these blocks he found that "sherds from the mortar [between the blocks] date from prehistoric times." 15

Stevens interpreted this wall section as a part of the Mycenaean circuit wall. In his argument he introduced for the first time the material excavated and reported by Kavvadias and Kawerau from under the Pinakotheke. His position was that these remains probably lay "within the walled area of the Akropolis [rather] than ... outside it," 16 and therefore he extended to the north the line of the newly discovered wall section to embrace these remains. In his reconstruction of the bastion area Stevens introduced cut steps with risers $0.15 \mathrm{~m}$. high and treads $1.25 \mathrm{~m}$. wide (Fig. 2). ${ }^{17}$ These steps bore no relation to the cuttings in the rock that had worried earlier generations. ${ }^{18}$

With the publication of Balanos' report in 1956, scholarly understanding of the state of the remains was clarified in a number of ways. ${ }^{19}$ First, the actual-state plan provides a stoneby-stone drawing of the bastion (cf. Fig. 3). It shows the terrace divided by a north-south crosswall set $c a .4 .50 \mathrm{~m}$. from the west face; this wall is founded on fill. Second, along the west face of the bastion was a niche with a stone post (indicated in Balanos' plan by a square block beneath the southwestern anta of the temple; cf. Fig. 3). The base of the niche is bedrock and has a raised circular bedding for a column (Fig. 4), an indication to Balanos that the present pillar is a later replacement of the Classical period. The pillar divides the niche in two; the niche is said to be a total of $5 \mathrm{~m}$. wide. ${ }^{20}$ Before the west face at the north side and in the upper surface of a projection of bedrock was a rectangular cutting, $0.30 \times 0.22 \mathrm{~m}$. and $0.15 \mathrm{~m}$. deep (at "135.30" in Fig. 3). North of it the rock surface was burnt and contained sherds.

15 Stevens 1946, pp. 75-106.

16 Stevens 1946, p. 73.

17 These steps were introduced to overcome the 25 percent grade of the rock along the north bastion face, which violated Stevens' 20th-century rule: "The maximum permissible grade for pedestrians should not exceed 14\%" (Stevens 1946, p. 77).

18 Stevens illustrated a nonexistent ramp resting on a ledge of rock about three meters wide, projecting from the base of the western bastion wall. This ledge was actually uncovered by Balanos (see Iakovides 1962, pp. 177-178 and p. 332 below).

The north-south polygonal wall used for Welter's guardroom was retained in Stevens' restoration, although he illustrated an open passage to a kind of "lovers' leap" off the southern face of the rock, and thus he honored the architectural separation of the bastion from the west fortification wall.

About the same time, W. B. Dinsmoor published his major article on the so-called Hekatompedon (Dinsmoor 1947), in which he illustrated (fig. 3) a plan of the Akropolis that showed what he believed to be the plan of the Mycenaean entrance system: the north leg of the Mycenaean wall is shown running along the line of the east foundation of the Pinakotheke. But his suggestion, made only in the illustration, received no notice until later.

19 Balanos himself did not publish his discoveries in full and did not risk a restoration of the remains of the Mycenaean period; see Mark 1993, pp. 1-3, 12-19 for a discussion of the problems of this report.

20 This measurement seems excessive and has caused confusion among scholars (see pp. 332, 341 below). Iakovides accepts the width and argues that a second column must have existed farther north in an area that Balanos was unable to investigate because of the unstable nature of the remains (1962, p. 111); Bundgård (1976, pp. 43-44, pl. G:iv) and Mark (1993, p. 14 and note 8) argue that Balanos erred when he reported a width of "about $5 \mathrm{~m}$." for the niche and that there was but one column within the niche. 


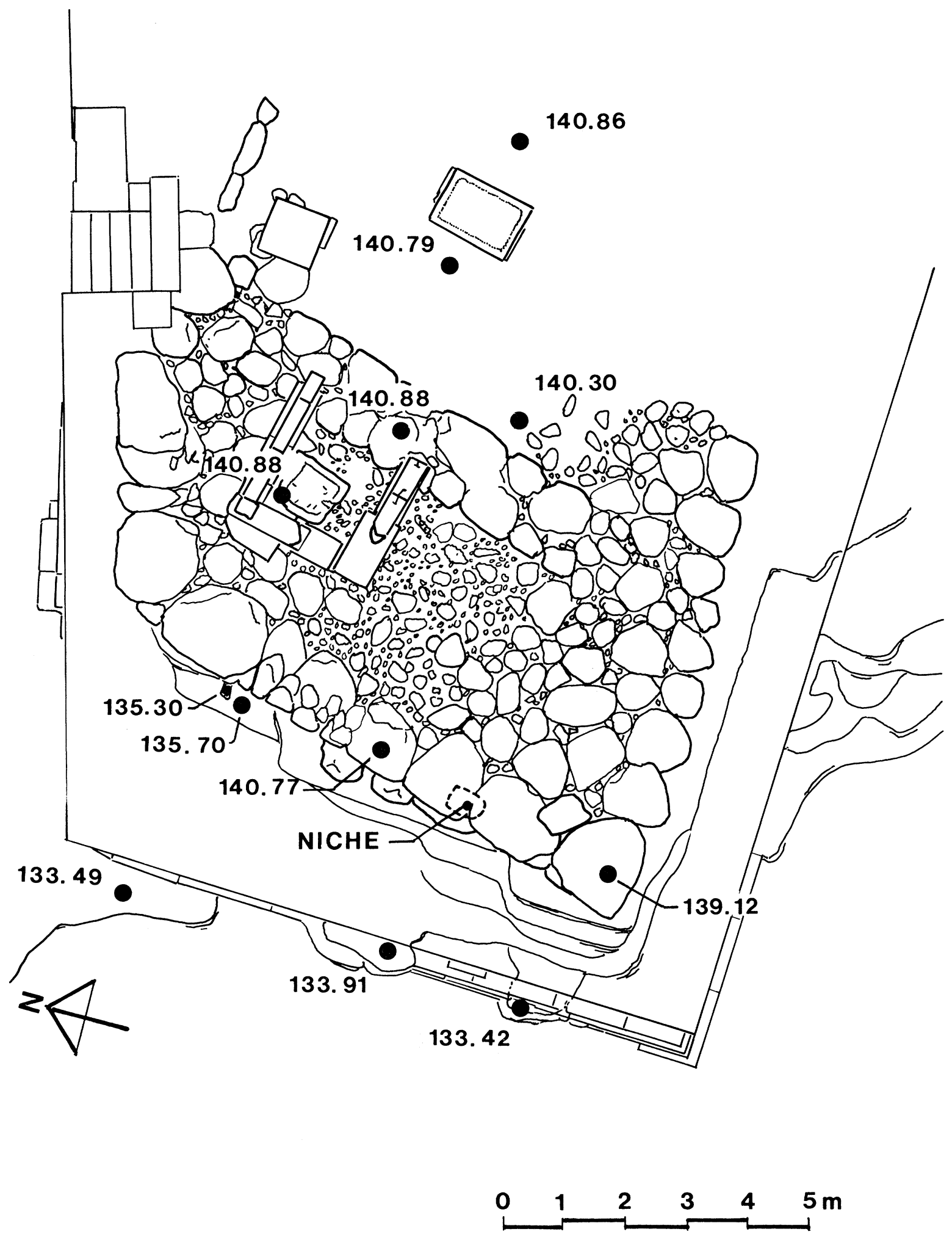

Fig. 3. Actual-state plan of the Nike bastion, after Balanos and Mark (J. C. Wright) 


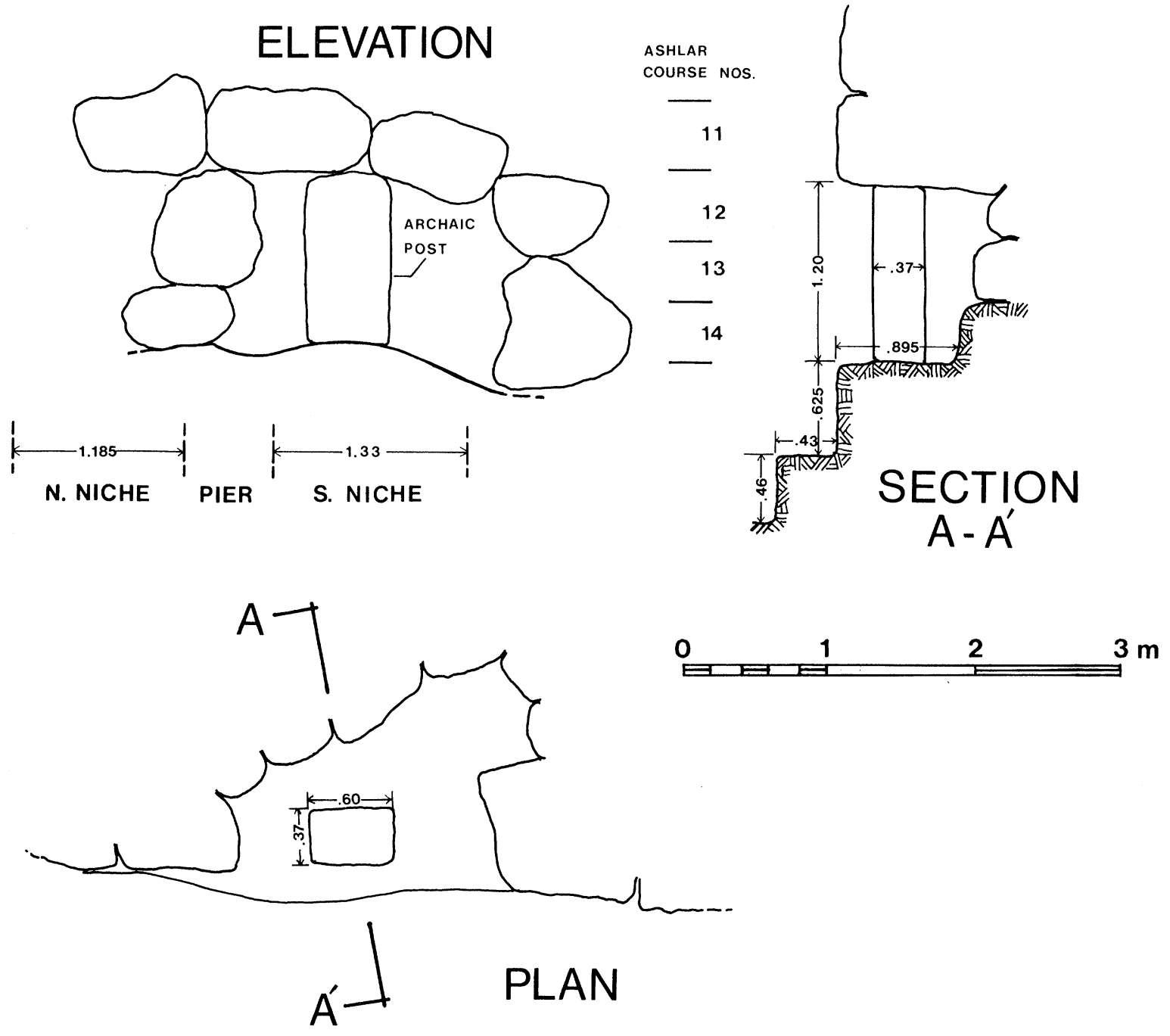

Fig. 4. Section and elevation of the niche (after Balanos' sketch and with permission of the Archaeological Society of Athens; J. C. Wright)

John Travlos first took advantage of this new source and produced a restoration of the entranceway that utilized the discoveries of both Stevens and Balanos (Fig. 2), ${ }^{21}$ although it retained the basic reconstruction of the bastion advocated by Welter. But it remained for Iakovides to make full use of this information. ${ }^{22}$ Combined with the results of his own critical autopsy, he produced a fully detailed discussion and a thoroughly documented set of plans. His illustration of the remains of the bastion was the first to attempt a complete

21 Travlos 1960, p. 25 and fig. 7; see also Hill 1953, fig. 3.

22 Iakovides 1962, pp. 106-117, 166-173. 
actual-state plan. It added to Balanos' plan by including the blocks of the southeastern side of the bastion and the north-south wall segment (cf. Fig. l) discovered by Bohn. ${ }^{23}$

Iakovides argued that the rectangular cutting, burnt area, and niche at the base of the bastion represent a shrine. The form of the niche presented a problem, however, owing to the ambiguity of Balanos' report regarding its size and form. Because the remains had been cemented over, Iakovides was not able to inspect them. He therefore calculated the dimensions of the niche indirectly, arriving at a width of $4.60 \mathrm{~m}$., and as a result argued for the existence of two pillars instead of one. ${ }^{24}$

Continuing his investigation of this area, Iakovides realized that the probable existence of a shrine here required a platform for access. Thus he modified Stevens' arguments for a passageway leading from the south side of the bastion around its west face and then, via stairs, along the steep north face. ${ }^{25} \mathrm{He}$ introduced to the discussion two massive projecting blocks, $2.50 \mathrm{~m}$. apart, that lie at the southwestern corner of the bastion (at "133.91" and "133.42" on Fig. 1). They are encased in ashlar masonry of the Nike bastion in a technique utilizing distinctive blocks of Piraeus limestone. ${ }^{26}$ Iakovides argued that this masonry marks the original level of Mycenaean construction at this point. He further observed a slight slope between the rocks (133.91 and $133.42 \mathrm{~m}$. above sea level on Figs. 1, 3), further evidence, he thought, for the incline of this platform.

Below these blocks are the bedrock steps, which Iakovides accepted as formed by leading animals up to the Akropolis. He argued that this path was Mycenaean by observing that these steps lie lower than the Classical remains of the bastion and the highest point of the Archaic terrace supporting the rampway of the entrance of the Akropolis. In his review of the scholarship surrounding the number and direction of the steps, Iakovides concluded that the path continued towards the Agrippa pedestal. He envisioned, then, two approaches: one with a reduced grade that switched back before entering the Akropolis, the other ascending up a stairway directly to the entrance (Fig. 2). ${ }^{27}$

Turning his attention to the north side of the entrance, Iakovides reexamined the area around the blocks discovered by Stevens north of the Nike bastion. Above and north of them he observed that the bedrock was worked back in a fashion characteristic of the Mycenaean remains on the Akropolis (at " 138.77 " on Fig. 1). ${ }^{28}$ These worked surfaces continue the line of the small stretch of wall next to them, and all these features fall within the line of a poros foundation projecting from beneath the western foundation of the Pinakotheke. Thus it is likely that they precede that foundation, which is Archaic in date.

Iakovides reconstructed these traces as the remains of a curving wall (Fig. 2). The interior face of the wall corresponds roughly to the line of the upper bedrock cutting, which he calculated lies about five meters behind the exterior face. In order to trace the Mycenaean wall farther north, he turned to the remains beneath the Pinakotheke. There, as we have

${ }^{23}$ The southeastern side is preserved only one course high and does not join with the polygonal wall at "141.96" on Figure 1.

24 Iakovides 1962, pp. 110-111, 118.

25 Iakovides 1962, pp. 171-173.

26 Balanos 1956, p. 791.

27 Iakovides 1962, pp. 112-113, 170-173, fig. 35.

${ }^{28}$ Iakovides 1962, pp. 113-114. 
seen, Kavvadias discovered a mass of large stones within which were the fragments of two walls. This fill contained Mycenaean debris to the height of a meter above bedrock. Iakovides interpreted these stones as coming from the collapse of the Cyclopean wall, which had zigzagged around the standing wall fragments on the interior. ${ }^{29}$ Following the lines prescribed by the Pinakotheke foundations, Iakovides reconstructed the wall running north and then east along the north side of the citadel (Fig. 2).

Continuing in this direction, there are scant traces of the wall with which to work. Iakovides recognized that the remains of the Archaic cistern established limits to the wall at the south. He observed a poros, slab-covered drain channel documented by Kawerau that wends its way to the west (Fig. l, arrow). Thinking this to be a drain from the Archaic cistern, he proposed that it did not go directly over the rock ledge to the north because the existence of the Cyclopean wall posed a natural impediment; therefore the channel wound along the inner course of the wall. Having thus argued for the position of the wall in this area, Iakovides then traced it eastward along the brow of the rock; there it loops north to a promontory where he identified a cluster of blocks from the original wall (at " 135.71 " on Fig. 1; Fig. 8). ${ }^{30}$

In summary, Iakovides suggested that the form of the west entrance was not unlike that of the Lion Gate at Mycenae. ${ }^{31}$ He argued against the freestanding tower-bastion restored by Welter and Travlos, pointing out that the bastion needed to be connected to the Cyclopean Wall. Thus he suggested a thick outer-gate wall linking the east end of the bastion with the curving wall to the north (Fig. 2). This leads to a cul-de-sac between the tower and the West Cyclopean Wall, exit from which was guarded by a second gate leading into the Akropolis. This gate system, as mentioned previously, was approached in two ways: directly via stairs and indirectly up the switchback path.

Iakovides' study has largely been accepted by the scholarly community. Reviewing the problem in 1966, George Mylonas suggested that the bastion was later than the fortification wall, ${ }^{32}$ and more recently Maria Pantelidou confirmed Iakovides' analysis. ${ }^{33}$ But an alternative explanation had existed since 1957. At that time Johannes Bundgård published his study of the architect Mnesikles, in which he considered the evidence for the Mycenaean entranceway. ${ }^{34}$ Bundgård concluded that Kavvadias and Kawerau's report on the fill within the Pinakotheke described the remains not of a fortification wall but of a terrace. He also took into account the trimmed areas of bedrock south of the Pinakotheke (Fig. 2). ${ }^{35}$ These, along with the stones uncovered by Stevens, he ascribed to a broad terrace which stretched from the center of the Mnesiclean entrance northwards under the

${ }^{29}$ Iakovides 1962, pp. 116-117; Mardonius and his army are blamed for the poorly preserved state of these remains.

30 Iakovides 1962, pp. 117-124, drawings 21-24, figs. 18, 19.

31 Iakovides 1962, pp. 166-173, figs. 34, 35.

32 Mylonas 1966, pp. 37-39, fig. 9:1, 2. Iakovides had already rejected this idea on the basis of the few sherds he found in his research: Iakovides 1962, pp. 104-105, 203, 205-208, esp. 239-245; Iakovides 1983, pp. 79-82 and esp. note 27 on p. 113. No sherd material from the bastion (Iakovides 1962, pp. 205-206) was preserved by Balanos.

33 Pantelidou 1975, pp. 24-27.

34 Bundgård 1957, p. 47.

35 Bundgård 1957, p. 194, notes 60, 61. 
entire Pinakotheke (Fig. 2). The Cyclopean wall he placed somewhere along the line of the eastern foundation of the Pinakotheke, an idea he may have derived from Dinsmoor's 1947 restoration. ${ }^{36}$ Bundgard asserted that this terrace continued to exist down to the time Mnesikles designed the Propylaia. ${ }^{37}$

This argument did not receive much notice. ${ }^{38}$ In 1976 Bundgård reiterated his views. ${ }^{39}$ For the northwestern area of the Akropolis, he largely followed Iakovides' arguments except to restate his own belief that the material within the Pinakotheke basement constitutes a terrace in front of the Mycenaean wall. ${ }^{40}$ Bundgård also attempted a series of elevation drawings of the remains of the bastion. ${ }^{41}$ His discussion centers on the idea that the Mycenaean bastion is a sheathing around a massive projecting section of bedrock, which was left exposed in three areas; the first two are along the northern and western sides, the latter preserving the niche with column, which Bundgård thinks was a place of veneration from at least Mycenaean times onward. ${ }^{42}$ The third is the top of the bastion, a terrace whose top surface was determined by the projecting bedrock. He then observes that the north-south crosswall, ca. $4.5 \mathrm{~m}$. back from the western face, formed an interior, higher terrace contained at the east by the roughly parallel, smaller eastern wall discovered by Bohn and used by Welter to form the eastern side of the pyrgos-tower. ${ }^{43}$ This entire complex, Bundgård maintains, is a shrine area with no defensive purpose. It remained as such until it was dismantled by the Persians in 479 B.G., after which it was restored as the Athena Nike sanctuary. ${ }^{44}$

After this reexamination the only research on these remains has been that of Dinsmoor, Jr., who treated them cursorily in his study of the predecessors of the Mnesiclean Propylaia. ${ }^{45}$ He believed that for any reconstruction of the Mycenaean remains to make sense it would be necessary to recognize that the Archaic gate was inserted into the gap between the northern and southern arms of the western Cyclopean wall. ${ }^{46}$ Dinsmoor agreed with Bundgård that

36 Bundgård 1957, pp. 49-50; cf. Dinsmoor 1947 and note 18 above.

37 His evidence for this belief is twofold. He thinks the lower western foundations are fanlike in form because they enclose the terrace fill, and he interprets the lower terrace remains in the Pinakotheke basement as being intact (Bundgård 1957, pp. 50-51). Originally they extended southwards out to the terrace wall of the Archaic rampway to the Akropolis.

38 Cf. Travlos 1971, p. 55.

39 Bundgård 1976. As has been pointed out (cf. Thompson 1978, pp. 256-258), the author covers virtually every problem ever raised about the Akropolis. One that absorbs his attention is the tradition of an Enneapylon. Bundgård restores four gates in the Mycenaean wall outside the western one, which he claims had five portals, just like Mnesikles', for a total of nine. Two of these lie along the course of the southern wall (pl. Kl). These reconstructions are completely hypothetical. The western one could not have existed where Bundgård places it because the wall lay to the north, as suggested by Iakovides (1962, p. 161, fig. 33) and verified by Robin Rhodes and John Dobbins (1979, p. 331, note 18). The western side of the north foundation of the Brauronion rests on a series of leveled-off Cyclopean blocks which rest on bedrock (a good actual-state plan is found in LaFollette 1986, p. 81, fig. 1; see also p. 80, note 23 ).

40 Bundgård 1976, pp. 38-39, note 92 and pl. F.

41 Bundgård 1976, pl. G; see also Bundgård 1974b.

42 Bundgård 1976, pp. 43-44, notes 107-108, figs. 22-24.

43 Bundgård 1976, p. 44.

44 Bundgård 1976, pp. 44-47; see Mark 1993, pp. 5-6.

45 Dinsmoor 1980, pp. xvii, 1-5, pl. 1.

46 Dinsmoor 1980, p. 2. 
the remains discussed by Stevens are not from a fortification wall and make more sense if from a terrace. Furthermore, he argued that the course of Stevens' wall not only was tortuous but also required an unusually narrow wall between the so-called house within the fill and the remains on the west side of the Pinakotheke foundations. Like Dinsmoor, Sr. and Bundgard, he positioned the northern leg of the Cyclopean wall under the area of the eastern Pinakotheke foundations (Fig. 2). ${ }^{47} \mathrm{He}$ also agreed with Bundgard that the entrance remained largely intact into the 5 th century B.c. ${ }^{48}$

This review has purposely given a detailed account of the evidence and the many interpretations in order to establish unambiguously the state of scholarship on this problem. Two facts about previous research are also revealed. First, except for Iakovides' study, most of the reconstructions are made in reaction to the discovery of pieces of the remains; none is based on thorough and critical autopsy of the entire body of evidence. Second, the tendency is to accept uncritically some features of the earlier researches. This is particularly true, as will be seen, with respect to the pathways at the base of the bastion and the evidence for the form of its upper part. In contrast, the present study is based on autopsy of all the evidence, which is illustrated on an actual-state plan and in a number of sections (Figs. 1, 5, 7). ${ }^{49}$ The review of the previous studies, which especially lack a consistent series of elevations above sea level, makes clear the need for a comprehensive measured plan. ${ }^{50}$ Thanks to the painstaking work of Bundgård, which made available the working notes and drawings of Kawerau, ${ }^{51}$ it is now possible to reconstruct accurately sections through the Pinakotheke basement that clarify the true state of the remains. Mark's study of the cult and sanctuary of Athena Nike provides hitherto unpublished material from the archives of Balanos' work on the bastion in 1939 and enables an accurate description of the bastion to be made. ${ }^{52}$ In addition, my own work on the Akropolis has clarified the state of many of the features, especially in the northwest corner.

\section{EVIDENCE AND INTERPRETATION}

\section{The ApProach}

The eleven rock steps before the west face of the Nike Bastion reported by Beule were still visible in 1979, when the present plan (Fig. 1) was drawn. ${ }^{53}$ They head northwards but curve slightly eastwards around the northwestern corner of the bastion. These are the same cuttings uncovered by Beule and recorded by Kawerau. The conformity of the modern record to these two earlier studies provides indisputable evidence of the state of these

47 Dinsmoor 1980, pp. 3-4, pl. 1.

48 Dinsmoor 1980, pp. 4-5.

49 This work was done with the assistance of W. B. Dinsmoor, Jr. during the summer of 1979.

50 This is a major failing of Bundgård's illustrations: the evidence for their determination is nowhere presented.

51 Bundgård 1974a.

52 I owe special thanks to Ira Mark for allowing me to read a pre-publication manuscript and also to the Archaeological Society of Athens for permission to publish the drawing used for Figure 4.

53 Beulé 1862, pp. 44-45, 68. They have since been cemented over to create a tourist path. 
remains. One must conclude that Bohn, despite his characteristic thoroughness, and Weller, despite his assertions of accuracy, were both mistaken. ${ }^{54}$

Beulé, Bohn, and Iakovides maintained that these cuttings were ancient. But Kavvadias and Kawerau suggested that they could as well have been made during the time of the medieval entranceway. This point bears investigation. One ought not accept blindly Beule's opinion that, since the steps were covered by a slabbed paving, they had been buried since antiquity. The same holds true for Bohn's argument, elaborated by Iakovides, that, because the cuttings lay lower than the Archaic and Classical rampways and beneath the sheathing of the Classical pyrgos, they must have preceded them. The major entrance to the Akropolis from at least Frankish times until Ross' work in 1833 lay adjacent to the bastion, and the path led directly over this area. ${ }^{55}$ In fact, as Travlos and Tassos Tanoulas have pointed out, ${ }^{56}$ the entranceway at the base of the Nike bastion was probably first constructed as a part of the defenses authorized by the Emperor Valerian. ${ }^{57}$ From this time the ascent to the Akropolis followed a switchback over to the Agrippa monument and then up to the Frankish tower, passing through a gate which lay over the preserved West Cyclopean Wall. ${ }^{58}$ Tanoulas, in a meticulous and highly informative recent study, has untangled many of the phases of the western fortifications during the 17 th century after Christ. So far as one can reconstruct the entranceway during this period, it appears that the upper, eastern, and steeper portion was constructed as a kaldirim, ${ }^{59}$ while the lower portion extending down from the gate below the Nike bastion over to the Agrippa pedestal was not so built, presumably because it represents a more gradual traverse. Whatever the case, the likelihood that it was between A.D. 267 and 1833 that this continuously used passageway received the cuttings in the bedrock is surely as great as that it was between the Late Bronze Age and the early 6th century B.C., when the Archaic ramp was constructed. ${ }^{60}$

The argument that the depressions in the bedrock resulted from leading animals up onto the Akropolis is a proposition that is virtually impossible to test. It is also dependent on the notion that the path leads over to the Agrippa pedestal, which it did from Late Roman times on but could not have done during the prehistoric period, when nothing interrupted the precipitous fall of the bedrock just north of the last rock cutting. ${ }^{61}$ Indeed, the entire northwest slope of the Akropolis is naturally inaccessible. The plan and section (Figs. 1, 5, Section c-c' $\mathrm{c}^{\prime}$ ) show how steep this drop-off is: behind the last bedrock cutting, on a line extending towards the Agrippa pedestal, the rock falls a full five meters. ${ }^{62}$

Even if we were to conclude, however, that the cuttings were used during the prehistoric period, what purpose could they have served? As Eugene Vanderpool pointed out, the

54 A survey of other literature on the approach to the Akropolis, not directly relevant to this study, is provided by Charles Picard (1929, pp. 15-18).

55 Travlos 1960, pp. 164-165, passim.

56 Travlos 1960, p. 165 and note 1; Tanoulas 1987, pp. 416-417, fig. 4.

57 On the date, see Travlos 1960, pp. 128-129 and notes 1 and 2, p. 129.

58 Travlos 1960, fig. 106; Tanoulas 1987, fig. 26.

59 Tanoulas 1987, p. 40 and figs. 26, 53, 54.

60 Vanderpool 1974, fig. 1.

61 Starting first with the 6th-century B.c. terrace and then with the 5th-century one and the Beule Gate, this area was gradually filled in to create a level area.

62 See also Dinsmoor 1931, fig. 3 (section). 


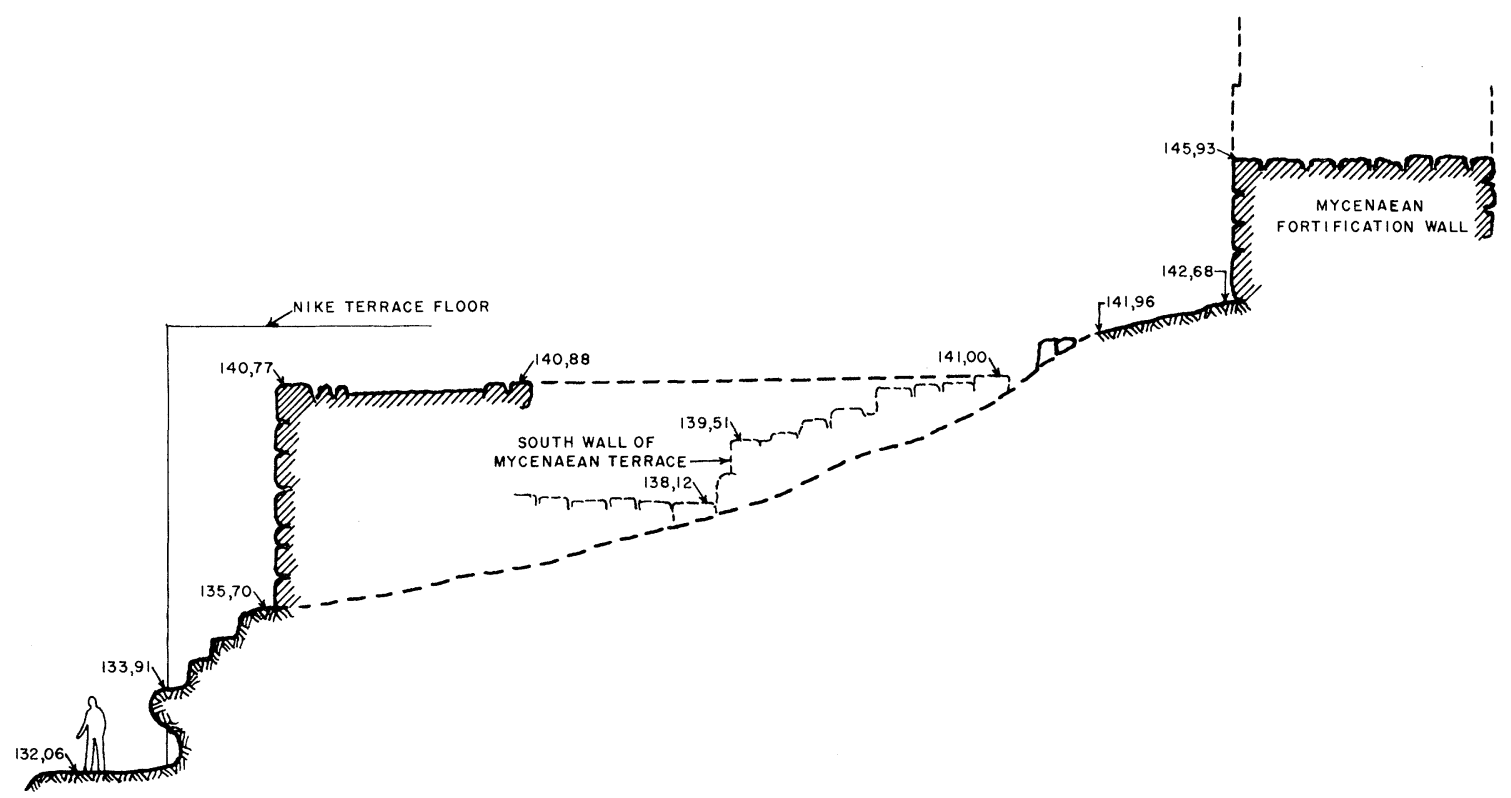

ELEVATION +130,00

SECTION $b-b^{\prime}$

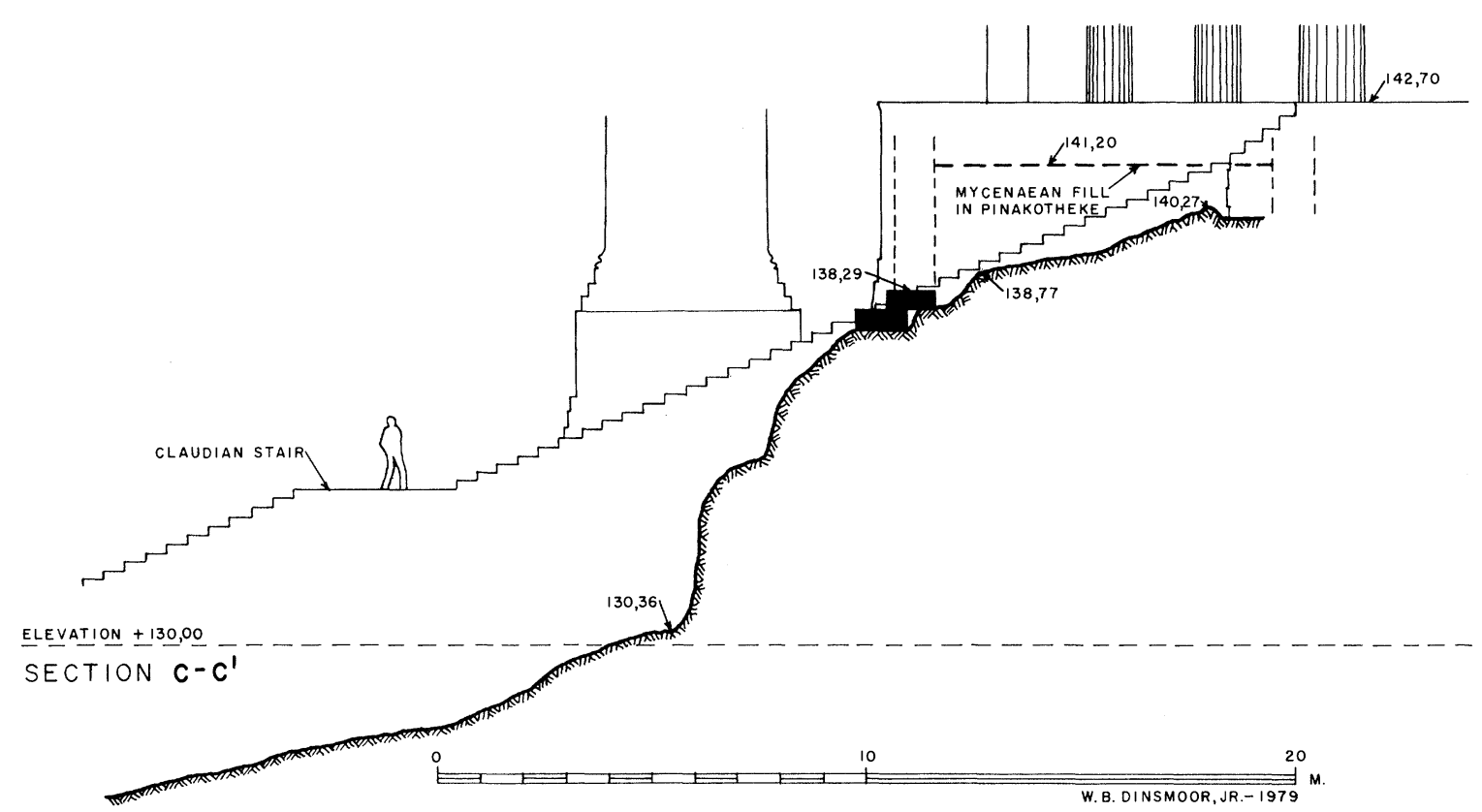

Fig. 5. Sections of the western end of Akropolis (cf. Figure 1; W. B. Dinsmoor, Jr.) 
natural ascent to the Akropolis is along the south side of the bastion and then around its west face. From there one must keep close to the outcrop of rock because of the declivity to the north. This route takes one from elevation $+130.49 \mathrm{~m}$. at the south to $+133.49 \mathrm{~m}$. at the northwestern corner of the bastion (Fig. 1). From there the ascent would enable access to the area of the square cutting (at $+135.30 \mathrm{~m}$.) or to the niche in the face of the Cyclopean bastion, or one could continue upwards toward the entrance. Thus there was no need for the terraced pathway across the western ledge as Stevens and Iakovides reconstructed it. Such a reconstruction runs against the evidence of the natural path just described. It would require a means of ascending from the path at the south (at +130.49 to $+131.16 \mathrm{~m}$., Fig. 1 ) to the southern end of the terrace, which could not have been lower than $+133.42 \mathrm{~m}$., the preserved top of the southernmost block supporting this terrace (Figs. 1,3). Thus the original prehistoric pathway may reasonably be restored closely skirting the projecting bedrock of the bastion and ascending eastward directly along its northern face towards the gate (Figs. 8, 9).

\section{The Bastion}

Although Welter gave an early report on the finds of the Mycenaean bastion, it was, as we have seen, only with Balanos' publication and Iakovides' reinvestigation that a substantive accounting emerged. Despite these sources there has remained confusion about the state of the remains. Bundgård in particular, as Mark has observed, misunderstood the evidence. Mark's work, taking into account the succeeding history, does as much as possible to clarify the record, which, because of the later use of the bastion for the Nike cult, may never be without ambiguity.

What Mark has provided that was hitherto inaccessible is evidence from Balanos' archives of the state of the bastion as it was revealed in the late 1930's. Balanos' newly published drawings and a close reading of his report allow an accurate view of the preservation of the bastion, especially along its southern and western sides but also for those parts preserved of the northern face. They also help our understanding of the form of the bedrock on which the bastion rests.

Bundgard presumed that the sheathing of the bedrock left sections of it exposed at the west, north, and on top. As Mark has pointed out, no evidence exists which shows that the upper surface of the bedrock at any point corresponded to the top of the bastion. ${ }^{63}$ Along the western side Balanos recorded that the bedrock was worked back to receive the lowest course of the Cyclopean sheathing. Such working, attested at many places on the Akropolis by Iakovides, ${ }^{64}$ may well have been effected on the other sides also.

Mark's publication of Balanos' elevations permits an appreciation of the Cyclopean masonry of the bastion. The west face is the best preserved and illustrates the tendency of Mycenaean masons to pay special attention to corners and important façades (Fig. 6) ${ }^{65}$ The blocks are set in regular courses, and the interstices are filled with smaller, often flat, stones

63 Mark 1993, p. 5, notes 25, 26, 27. It is true, however, that we do not know the height of the bedrock in the eastern area of the bastion, behind the north-south crosswall.

64 Iakovides 1962, pp. 113-114, 121, 127, 140-141, 148-149.

65 Wright 1980, pp. 66, 70, 75-76; in fortifications the placement of especially large and regular blocks around the entranceways is known from Krisa, the Teichos of the Dymaians, Gla, Tiryns, and Mycenae, to name the most outstanding examples. 


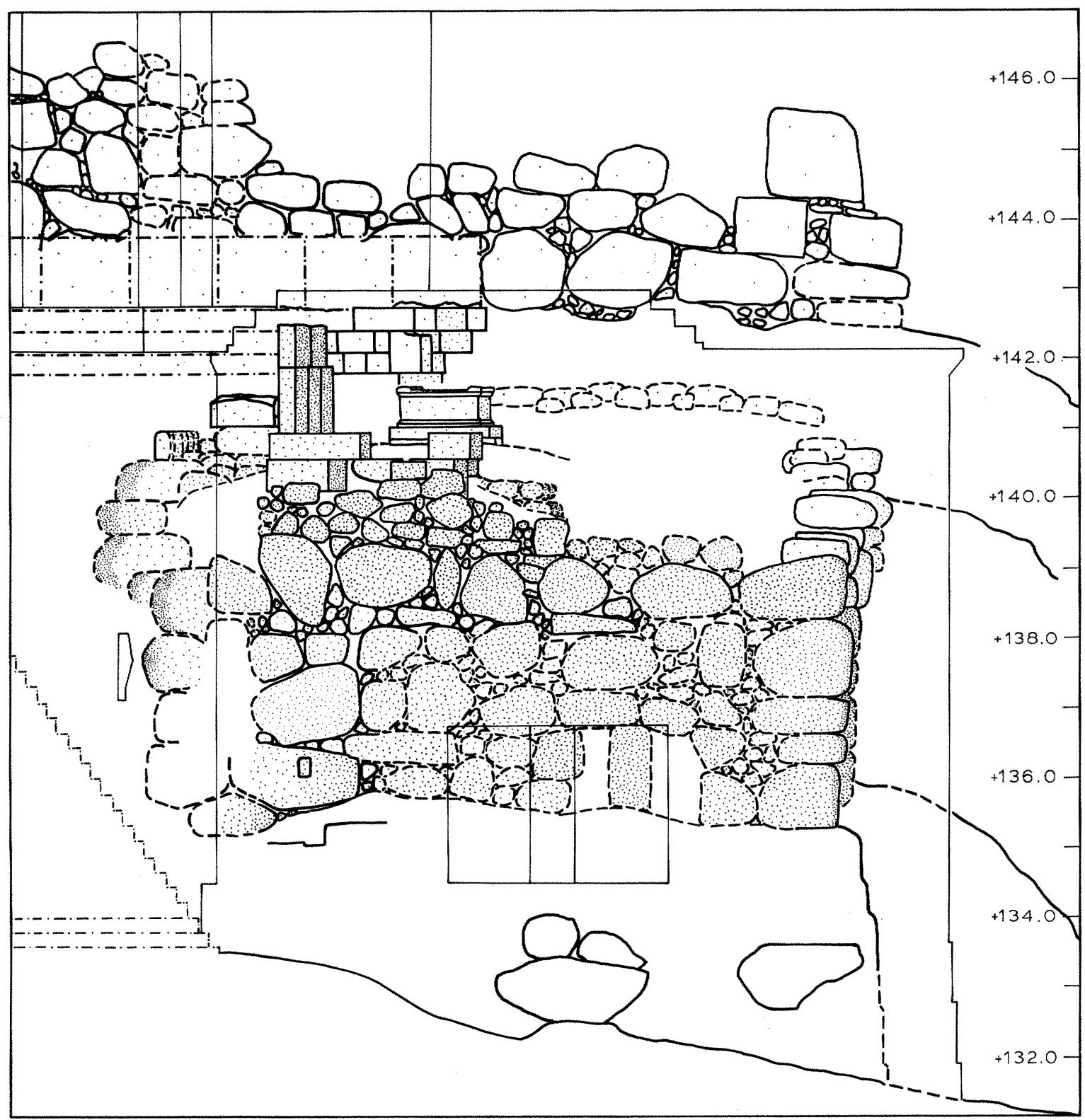

Fig. 6. Elevation of the western face of the Nike Bastion (Mark 1993, fig. 16)

and mortar. ${ }^{66}$ On the south side large blocks are stacked together next to the corner, but eastwards the masonry (preserved only in two courses) is formed with smaller stones and the coursing is less carefully attended.

66 Welter 1939, col. 6; Balanos 1956, p. 787; compare the appearance of the west bastion façade to the masonry of the Cyclopean bridge at Agios Georgios at Mycenae (photograph in Wace 1949, fig. 38:a). 
Mark argues that the rubble stonework uppermost on the bastion is part of a later rebuilding of its crown. He draws attention to Welter's and Balanos' observations that these courses consist of smaller stones built as dry wall with a reddish earthen fill behind them. ${ }^{67}$ This change is apparent in the elevation of the west face published by Mark (Fig. 6), and there should be no doubt that his conclusion is correct. Probably all the blocks atop the uppermost course of the Cyclopean wall face are part of this rebuilding. Mark argues cogently that this rebuilding belongs to the period between Late Geometric and Early Archaic. It is unfortunate that this interpretation must rest on an analysis of masonry alone, for the sherd material recognized by Welter was only of Middle and Late Helladic styles. ${ }^{68}$

Apparently the damage to the bastion did not much affect its core. The north-south crosswall found within seems Mycenaean in style and original to the bastion. Its southern side is not well preserved; perhaps it fell away when the crown of the bastion gave way. Bundgård thought the wall retained an upper terrace, but it is not built as such, having instead two faces. ${ }^{69}$ Since it is based in the fill and not on bedrock, it seems unlikely that it served to break up the load within the terrace. These observations and its great thickness $(1.45 \mathrm{~m}$.) strongly suggest that it was a bearing wall. It was preserved to $140.67 \mathrm{~m}$. above sea level. ${ }^{70}$ This height is slightly lower than the easternmost block of the bastion, the top of which is at $+141.00 \mathrm{~m}$. (Fig. 1). ${ }^{71}$ If the crosswall was built for a superstructure on the bastion, then it is unlikely that what is preserved today is very much below the original ground level of the bastion; perhaps as much as $0.50 \mathrm{~m}$. to $1.00 \mathrm{~m}$. is missing. This line of reasoning permits an estimation of the top surface of the Mycenaean bastion at $c a .+141.00$ to $+141.50 \mathrm{~m}$.

In most reconstructions, starting with that of Welter, the small section of masonry to the east (near "141.96" on Fig. 1) is taken as the inner face of a tower built over the bastion. Mark has rejected this purpose for this wall and instead claimed it for the eastern limit of the rebuilt crown of the terrace. ${ }^{72}$ His analysis is in agreement with my own independent observation that this eastern line of wall is not part of the Mycenaean bastion and is not even of Mycenaean character.

As recorded by Kavvadias and Kawerau, there was nothing about this wall that aided its interpretation. ${ }^{73}$ They cemented over it, and so it cannot be inspected today. It is reported, however, as being made up of small limestone rubble, not, according to their use of terms, Akropolis limestone, which is normally employed in the Cyclopean masonry of the Akropolis. There being no reason to view it as Mycenaean, there is less reason to accept Welter's decision to use it to restore the form of the Mycenaean bastion, even less so if it fits, in position and style, with the rubble masonry forming the crown of the rebuilt bastion.

${ }^{67}$ Mark 1993, pp. 15-17.

68 Welter 1939, col. 8.

69 Although interior walls to redirect the weight of terrace fills are not uncommon in Mycenaean terraces, such walls are not usually built with two faces. Where they do occur, the fill is not very deep, and most examples are early, e.g., at Malthi, in the second mansion of the Menelaion; see Wright 1978, pp. 66-79; Wright 1980, pp. 61-64.

70 Actually it is preserved today to $+140.88 \mathrm{~m}$., but Mark has determined that when Balanos reconstructed the wall he set it $0.21 \mathrm{~m}$. higher than it had been originally (Mark 1993, p. 13, note 5).

${ }^{71}$ Mark records this block at $+140.67 \mathrm{~m}$.

72 Mark 1993, p. 16.

${ }^{73}$ Kavvadias and Kawerau 1906, col. 140. 
Despite dismissing this wall from consideration, Mark has argued that the bastion, in its capacity as outer defense to the Cyclopean circuit, must have risen much higher than preserved today. He suggests a height of some ten meters above the base of the bedrock at the west, to $c a .+144 \mathrm{~m}$. The weakness of this suggestion is that it postulates remains where no evidence exists (the gate wall of Mark's proteichisma) and does not make good sense of the existing crosswall, which is viewed more comfortably as an element of the superstructure. ${ }^{74}$

Mark also researched the reported evidence concerning the area of the niche. ${ }^{75} \mathrm{He}$ does not accept Iakovides' conclusion that there were originally two columns. Rather, he points out that Balanos' drawings show only one niche, exactly what was reproduced in the Classical bastion. This is verified by Balanos' hitherto unpublished sketches of the niche (Fig. 4), which show its precise limits and preclude further debate about it. ${ }^{76}$

What is there then to say about the Mycenaean remains of the bastion? From all the evidence gathered here it would seem to have been a formalization of the natural bedrock of the area at the end of the Late Bronze Age, perhaps as part of a systematization of defenses on the Akropolis, perhaps as a monumentalization of the entrance. The massive crosswall built parallel to the western face may indicate that a rectangular room or solid tower was erected at the west end of the bastion (Figs. 8, 9). The lack of remains along the north side hinders our understanding of the form of this arrangement. It may have been entered directly from the ground level of this area (at $c a .+142 \mathrm{~m}$.) to the rear of the bastion terrace. A stairway may have been built into the tower, ascending to its platform.

Assuming that Mark's interpretation of the evidence of the early collapse of this tower is correct, it is likely that the original form of the bastion was never known in Classical antiquity. Following the suggestion advanced here, however, the back terrace would have been mostly intact and provided the surface on which the cult of Athena Nike was founded. The one enduring and impressive remnant was the niche with its column, a symbolic element that made a strong impression on the early Athenians. ${ }^{77}$

\section{The West Cyglopean Wall}

By all accounts this wall formed the primary defense of the Akropolis along its western flank. It is distinct from the other traces of the Cyclopean wall because of its great thickness ( $c a$. six meters) and its unusual straightness. Its course to the north has recently been demonstrated to have extended farther than previous evidence warranted. The cutting for the metopes (at "142.41" on Fig. 1) facing it in the period preceding the Persian sack extends northwards, adding about three meters to the known length of the wall. ${ }^{78}$ Iakovides and Bundgard discussed the evidence for the height. ${ }^{79}$ It is preserved today $3.45 \mathrm{~m}$. above the bedrock. In the 5th century B.C., however, it was preserved much higher. Bundgård thinks

74 Mark (1993, p. 15) bases his reconstruction on Travlos (Travlos 1971, fig. 67).

75 Mark 1993, p. 14 and note 8.

76 Iakovides 1962, pp. 110, 111, 118; see note 20 above.

77 For interpretations of the niche, see Charitonides 1960, pp. 1-3; Iakovides 1983, p. 30; Wright forthcoming.

78 Eiteljorg 1975, pp. 94-95; Dinsmoor (1980, pp. 17-41, passim) discusses the implications of this discovery; see Eiteljorg, in press, which also argues that the western wall was partially destroyed by Mardonius and reerected during the 5 th century.

79 Iakovides 1962, p. 163; Bundgård 1957, p. 78; Dörpfeld 1885, p. 139, pl. V:3, 4. 
Mnesikles had no intention of dismantling any portion of the wall, because he fitted the southeast corner of the south wing of the Propylaia, from the geison downwards, against the Mycenaean wall (cf. +145.93 m., top of wall, Fig. 1). ${ }^{80}$

The wall and the bastion were clearly separate elements. The former is based higher than any preserved elements of the latter $(+142.68 \mathrm{~m}$. compared to $+141.00 \mathrm{~m}$.). There are no indications that the bastion was in any way built against the exterior face of the wall. At the north, there remain no indications of how the wall formed part of the gate into the Akropolis.

\section{The Area Around the Pinakotheke}

Stevens' discovery of the curving line of stones in the area of the western ascent enlarged the discussion about the shape of the Mycenaean entrance system. Unfortunately, he neither published the sherds he found nor produced an accurate plan of the remains. Figure 1 includes the worked ledges of rock at the north recorded by Iakovides. As Bundgård has argued, these remains are not proof of the existence of a Cyclopean wall here. ${ }^{81}$ The blocks are certainly not Cyclopean in style, and, though they may have been merely leveling stones for the superstructure, such a practice is not common in Cyclopean masonry. ${ }^{82}$

The line connecting the remaining stones and the bedrock cutting falls just within the poros foundation projecting south from beneath the Pinakotheke foundations (p. 332 above and Fig. 1). Bundgard has cogently argued that this foundation is part of a predecessor to the Pinakotheke, where it was used for the western foundation. When it was incorporated into Mnesikles' plan, the shift in orientation of the Propylaia created the fanlike shape of the foundations. ${ }^{83}$

Stevens and Iakovides used the remains found in the Pinakotheke basement as indicators of the northward course of the Mycenaean wall, while Bundgård and Dinsmoor have argued that they are the remains of a terrace. Bundgård's publication of Kawerau's field drawings provides more evidence than can be gleaned from Kavvadias and Kawerau's publication. ${ }^{84}$ This drawing is presented as Figure 7, which shows Kawerau's plan and section through this area; absolute elevations have been calculated on the basis of his measurements from the top

80 Bundgård 1957, p. 78. One fact of interest in understanding the state of these remains in later times is that the wall as preserved today was buried in the 17 th century by an entrance ramp that ran over it (Tanoulas 1987, figs. 15, 26; cf. figs. 40-42, 53, 54). The ramp was an element of the entranceway established at the beginning of the 13th century with the construction of the Frankish gate tower (Travlos 1960, pp. 165-166, fig. 106).

81 Bundgård 1957, pp. 48-49.

${ }^{82}$ In my study of Mycenaean masonry techniques (Wright 1978, pp. 33-41) I document how Mycenaean walls of massive rubble masonry were formed of massive blocks even in their lowest course. Although cutting back the bedrock or extending the base blocks beyond the face to create a footing were common techniques to support the walls, to my knowledge their outer faces were never based on surfaces made of smaller stones.

${ }^{83}$ Bundgård 1957, p. 51. According to Bundgård (p. 52) these foundations were renewed in 1878. A stone-by-stone plan (Fig. 7) was drawn by Kawerau; it shows the lowest course on the interior following the alignment of the projecting foundation (Bundgård 1974a, p. 1). It is not possible to view these details today because the interior of the foundations was shored up with cement in 1955 (Daux 1956, p. 231).

84 Bundgård 1974a, pl. 1 (= Kawerau's plate I). 


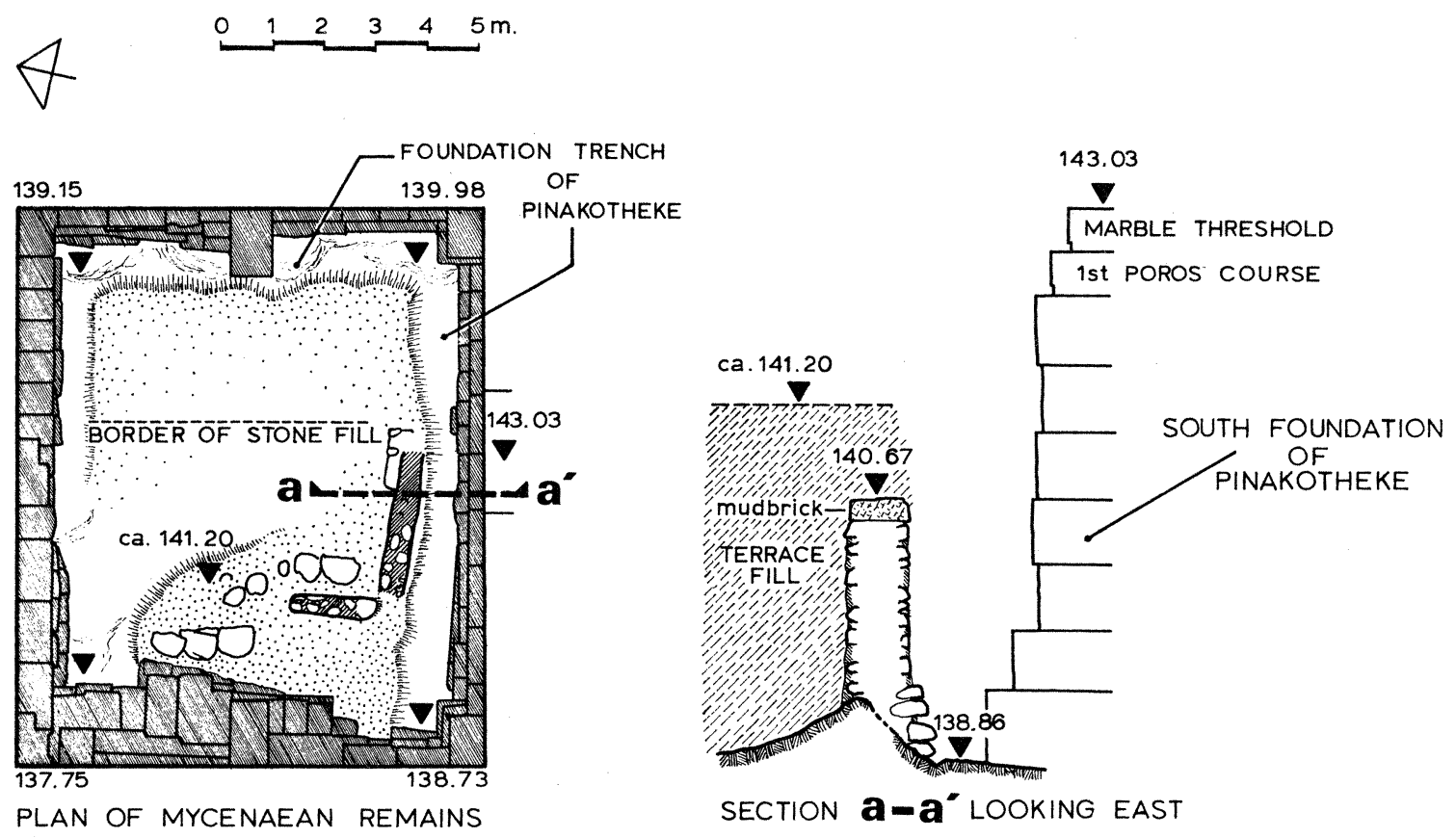

Fig. 7. Actual-state plan of the Pinakotheke and reconstructed section, after sketches by G. Kawerau (J. G. Wright)

of the threshold block. These show that the fill in the basement consisted of a western portion of stones and an eastern one with an earthen fill. ${ }^{85}$ Within the fill were encased the two wall fragments, which apparently were from different buildings, ${ }^{86}$ these were founded on the bedrock. The fill had been cut through at the time of the establishment of the foundation of the Pinakotheke, ${ }^{87}$ it contained exclusively Mycenaean and pre-Persian material. ${ }^{88}$

85 Bundgård 1974a, p. 33; on pl. 1 (no. 7) Kawerau states: "Ungefähre Grenze der Steinschüttung; hoch bis 1,5 unter Schwelle; in diesem Theil alte Erde mit myken. Funden."

86 Bundgård 1974a, p. 33; on pl. 1 (no. 5) Kawerau states: "die kleine Mauer steht $50 \mathrm{~cm}$ höher als die längere.... Unter der längere Fund einer älteren Mauer $10 \mathrm{~cm}$ üb[er] Fels; auf der längerem einige Lehmziegel."

87 The foundation trenches are indicated by dotted dashes in Kawerau's drawing and also in the sections (Bundgård 1974a, pls. 1, 2). The foundation trenches are shown along the eastern and southern sides. Bedrock showed along the northern side, as if the prehistoric fill were not well preserved there. The lack of indication of a trench against the west side is evident; Kawerau drew the fill running against the west foundation. This indicates, I believe, that the remains in situ must have been much as Bundgård thought them: a preexisting structure sheathing the remains along the west.

${ }^{88}$ Kavvadias and Kawerau 1906, col. 60: "nur Topfscherben mykenischen Stils und sonstige Stücke aus vorpersischen Zeit fanden"; cf. cols. 41-42, 44 and Wolters 1889, p. 121: “. . fast ausschliesslich mykenische Topfscherben; jüngere Funde werden dagegen nur dicht an den Fundamenten gemacht, für welch man in das Erdreich einen Graben eingeschnitten hatte, der nachher wieder zugeworfen wurde." 
Following the indications in Kawerau's plan, it is possible to calculate the preserved height of the fill as $c a .+141.20 \mathrm{~m}$., the top of one of the wall stubs as $+140.67 \mathrm{~m}$., and that of the other as $+141.10 \mathrm{~m}$. (Fig. 7). Thus it is clear that the walls were embedded within the fill.

It has been established that this fill is probably intact and that it originally extended farther south. The question remaining is what it tells us about the true state of this area in the Late Mycenaean period. The mere presence of two rubble walls founded on bedrock is proof that in an early phase this area bore structures. For Stevens and Iakovides this implied that the addition of the circuit wall respected those structures. Iakovides thought that the fill found in the Pinakotheke basement had collapsed from the fortification wall. ${ }^{89}$

The alternative theory, that this fill represents a Mycenaean terrace, is based on the assumption that what exists today has not changed since it was first set in place and that the remains to the south better suit a terrace than a Cyclopean wall. The additional information from Kawerau's notes lends support for this interpretation in three ways. First, it is clear that the fill was used as a terrace preceding the Pinakotheke because of the unity of the fill with the earlier western foundations. Second, the description of the fill as consisting in its western portion mostly of stones is consistent with the construction of Mycenaean terraces. ${ }^{90}$ Third, the preservation of the fill to a height of $+141.20 \mathrm{~m}$. is very close to the preserved maximum height of the Mycenaean bastion to the south, and if the suggestion given above for restoring the bastion as a terrace extending from the Cyclopean wall out to a western tower is correct, then it would appear that there existed two terraces, each about the same height $(+141.20 \mathrm{~m}$. and $+141 \mathrm{~m}$.).

Yet these arguments do not actually demonstrate the existence of a Mycenaean terrace so much as they establish the likelihood that a terrace stood in this area prior to the Persian War. The excavators reported both Mycenaean and later, pre-Persian pottery from the fill in the Pinakotheke basement. Thus it could be that the fill was deposited and the terrace wall constructed in the Late Geometric or Early Archaic period. Although this is highly speculative, such an activity might have occurred in concert with the construction of the first precinct of Athena Nike atop the bastion. ${ }^{91}$ The creation of a secondary terrace would have cleaned up the remains standing outside the wall (for instance, the two wall stubs found in the fill) and provided more space for early worship in this area of the Akropolis. This interpretation, however, will not be adopted in the conclusion of this study because it would have to ignore the evidence of the Mycenaean bedrock cuttings between Stevens' wall fragment and the Pinakotheke.

From the viewpoint of the construction of Cyclopean walls, the placement here of a massive wall would present some difficulties. The bedrock levels between the interior and exterior faces would vary between $+138.73-138.77 \mathrm{~m}$. for the former and +136.00 $137.31 \mathrm{~m}$. for the latter (Figs. 1, 5). These dramatic differences are recorded within four meters of each other, and extensive dressing of the bedrock would certainly have been required to form ledges for placement. Although such trimming is generally rare in

89 Iakovides 1962, p. 116.

90 Note 69 above.

91 Mark 1993, pp. 15-17. 
Mycenaean Cyclopean masonry, ${ }^{92}$ it is known on the Akropolis: Iakovides reported it in the area east of the Erechtheum, although not so extensively as required here. ${ }^{93}$ Other than the bedrock cutting recorded behind the projecting poros foundation wall, no traces of such cuttings are known in the area of the Propylaia, although of course they could be hidden from view, if not altered by the western foundations. Such a solution, however, requires that the wall run within the line of the foundations, ${ }^{94}$ whereas the curving portion of wall to the south clearly has its exterior face well within the inner line of the poros foundation. If this line is projected northwards within the area of the Pinakotheke, a mere 2 to $2.5 \mathrm{~m}$. is available for the width of the wall. This was the basis for Dinsmoor's objection to this wall. ${ }^{95}$

Evaluating the evidence and arguments, it is possible to believe that the hypothesis of a terrace is the best supported. All in all, however, neither objections to a wall nor arguments in support of a terrace decisively resolve the matter. Thus, ultimately, the choice of solutions must be left to individual preference.

\section{The Remains at the Northwest}

The quandary is exacerbated, however, when one turns to the remainder of the evidence cited by Iakovides for the continuation of the wall along the north side. On the basis of the evidence for the course of the drain, he argued that the wall was positioned along the brow of the rock above the Cave of Apollo. ${ }^{96}$ As demonstrated in the Appendix (pp. 357-358 below), this argument was founded on a mistaken attribution of the drain to the Archaic period. In fact, the drain is Classical in date, part of the reorganization of this area after the Persian sack. The only solid evidence, then, is the cluster of stones on the leveled bedrock projecting immediately east of the area of the caves (near $\mathrm{E}^{\prime}$ on Fig. 1). ${ }^{97}$ These lie over fifty meters away from the west front of the Propylaia, and this great distance illustrates the magnitude of uncertainty concerning the course of the Mycenaean wall in this area.

Between the blocks resting on the promontory of the north face and the remains at the west lies a nearly insuperable obstacle to determining the northward course of the Cyclopean wall, namely the Archaic cistern (Figs. 10-12; Appendix). As is apparent from a glance at the plan (Fig. 1: E), this structure is so located that it lies in the path of any northward projection of the Cyclopean wall. Its presumed construction and use before the Persian war suggest that it existed when the Cyclopean wall was still in use. Therefore any reconstruction of the course of the wall has to take its position into account. It is natural to presume that such a structure would have been placed within the course of the defensive wall. The wall is not likely to have run east of the cistern, for example as a northward extension of the existing West Cyclopean Wall, because its northern end would then fall over fifteen meters beyond (east of) the trace of wall

92 Wright 1978, note 43. In general, Mycenaean masons preferred not to dress back extensively any hard limestone bedrock when constructing Cyclopean walls. This stands in contrast to the frequency with which this practice occurred in Hittite citadels (see Naumann 1971, pp. 55-57).

93 Iakovides 1962, pp. 139-143 and esp. fig. 23, p. 142.

94 Iakovides 1962, fig. 20.

95 Dinsmoor 1980, p. 3.

96 Iakovides 1962, p. 119.

97 Iakovides 1962, pp. 119-122. 


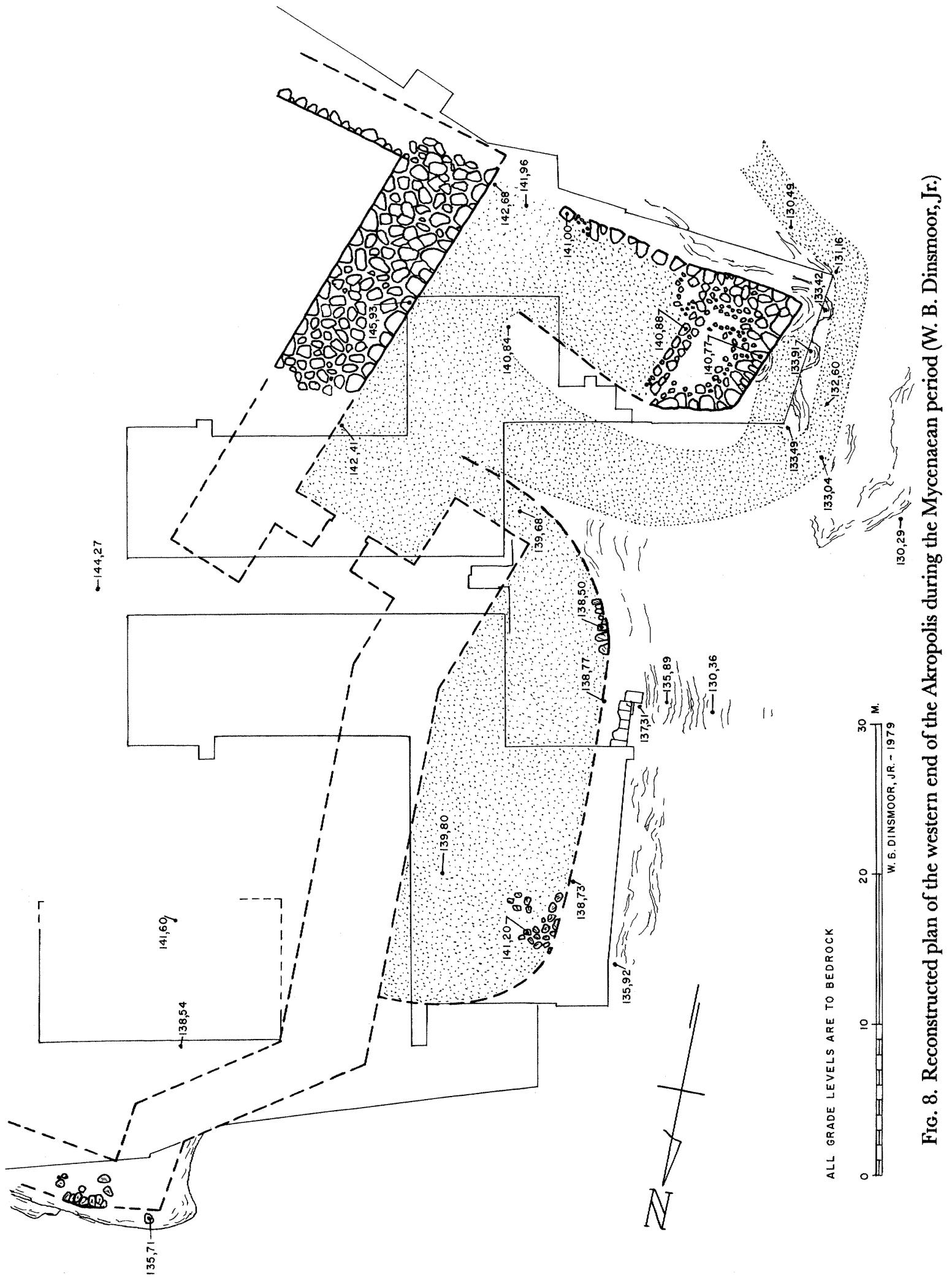




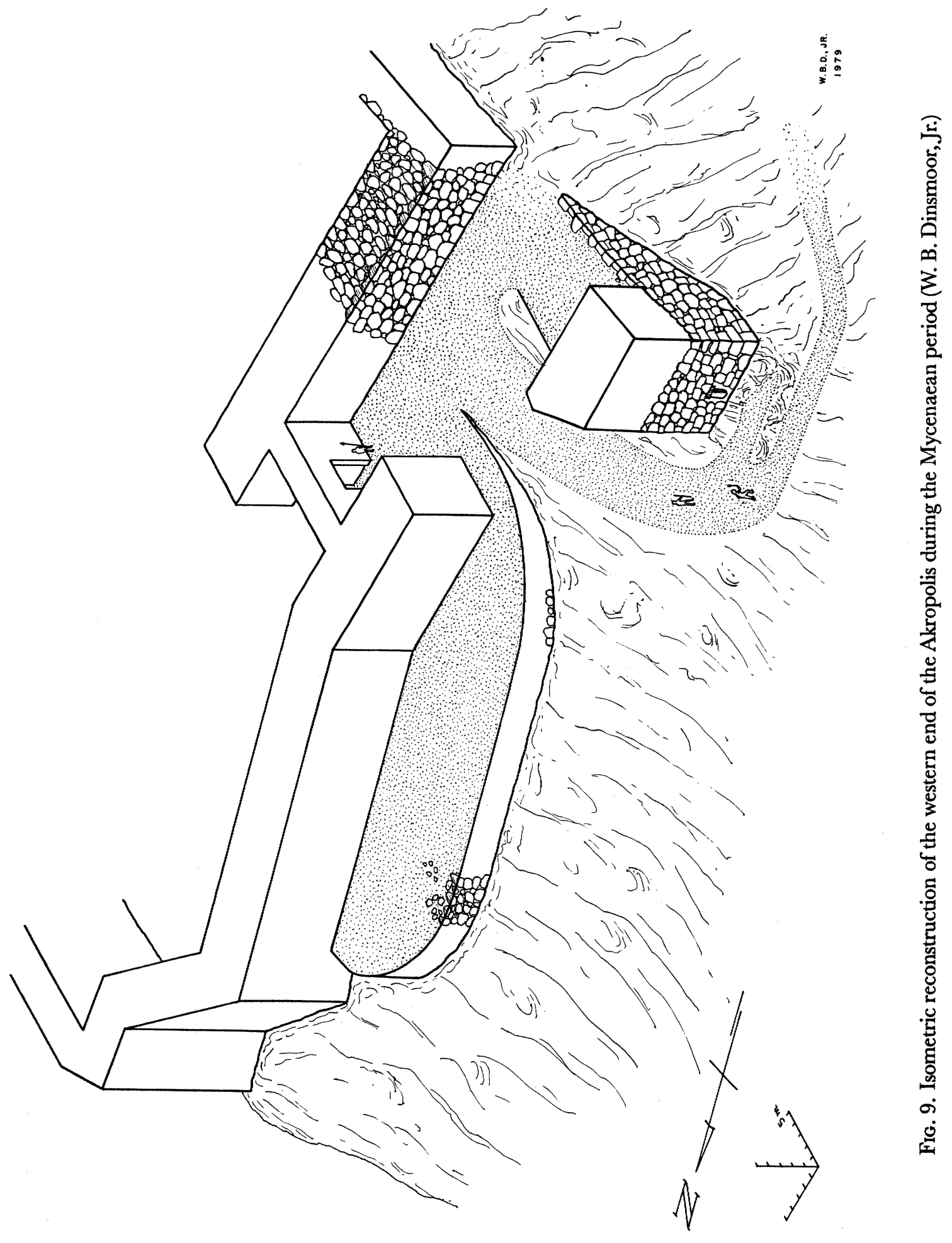


on the projecting ledge of rock at the north (at $\mathrm{E}^{\prime}$ on Fig. 1 ) ${ }^{98}$ Moreover, such an arrangement would expose the water source, leaving it outside the defensive walls. The remaining choice, then, is to run the wall from this ledge around the cistern at the west. If the wall did not continue farther westwards as Iakovides argues, then it would stay on higher ground ( $c a$. $+140 \mathrm{~m}$.) and run south to overlap with the preserved West Cyclopean Wall.

As reconstructed in Figures 8 and 9, the Cyclopean wall forms an oblique entrance of the type favored by students of military architecture because attackers are exposed to enfilading fire on both flanks. In this case the enemy would also have to contend with defenders in the tower and on the bastion, who would not only control the approach to the gate but also expose any enemy attacking the gate to fire from behind. Instances of such a gate system in Mycenaean defensive architecture are in fact quite rare and always late in the development of Mycenaean fortifications. Often cited are the Lion and North Gates at Mycenae, both developments of the Late Helladic (LH) IIIB period. ${ }^{99}$ At Tiryns this system is not employed except for the interior gateway, the so-called Steintor, which is flanked by the palace terrace and the interior of the fortification wall. ${ }^{100}$ Otherwise, all the gates, even of the latest period, are set perpendicular to the fortification wall. ${ }^{101}$ Elsewhere, the only other claimed instance of such a gate is the South Gate at Gla, ${ }^{102}$ but in fact the overlap of the wall here is probably more strongly influenced by the terrain, which requires it to zigzag at this point. The gate itself is a special variety of thickened perpendicular opening developed at Gla and also used in the early gate at Tiryns. ${ }^{103}$ The western walls and gate system at Athens would, then, be best viewed as a late development in the history of the citadel.

Without the possibility of inspecting the pottery remains from the terrace fills from the Pinakotheke and the Nike Bastion, one cannot properly assess the date of their construction (see p. 343 above). ${ }^{104}$ The possibility raised by Mylonas, ${ }^{105}$ that the West Cyclopean Wall and the bastion are of different phases of construction, may be entertained. It has often been observed that the former is both dramatically thick in construction and unusually straight in its course. In these respects it stands apart from the remainder of the circuit wall that has been exposed and studied. Kawerau's plans also show an awkward joint between the

98 These blocks contained sherd material in the mortar between them; they date between Middle Helladic (MH) and developed Late Helladic (LH) III (Iakovides 1962, pp. 244-245).

99 See Mylonas 1965 for the study of these gates and their dates. See also Iakovides (1983, pp. 29-35), and Hope Simpson and Dickinson (1979, p. 36), who convincingly argue the date for these installations to be early LH IIIB: 1 .

100 Müller 1930, pp. 63-73.

101 Iakovides 1983, pp. 10-11; Kilian 1978, fig. 1 (actual-state plan of the Unterburg walls).

102 Iakovides 1983, pp. 95, 105.

103 At Gla the distinctive form of these gates is seen in the thickened bastions around the entrance and the addition of guardrooms inside the gate (see Iakovides 1983, fig. 14). At Tiryns this system was employed for the first gate of LH IIIA date (Müller 1930, p. 62), which during its second phase is augmented on the interior, much like the inner guardrooms at Gla. This system is therefore confined to an early period in the history of Mycenaean fortifications, bracketed between LH IIIA:1 and the very end of LH IIIA:2 (Iakovides 1983, p. 105, pl. 76.).

104 Sherds recovered by Iakovides, however, from the interstices of the blocks resting on the projecting ledge of the north side (Iakovides 1962, pp. 244-245), date from MH to developed LH IIIB.

105 Mylonas 1966, pp. 37-39, fig. 9. 
southern end of the West Wall and the western end of what is preserved of the southern one. These are inaccessible today, but it seems possible that the joint could be evidence of an awkward fitting of the West Cyclopean Wall into an existing construction. Such a situation would imply an early fortification that was arranged at the west into two defensive terraces (perhaps crowned with a battlement), which flanked the steep approach and funneled traffic around the southern bastion. ${ }^{106}$ Thus it seems quite possible that in the later LH IIIB period, when other citadels were experiencing additions to their defensive arrangements, a new western gate system was erected on the Akropolis.

Although this reconstruction is hypothetical, it succeeds in making sense of the existing remains in many ways. As the earliest elements of a system of fortifications, the bastion and terrace provided an adequate defense to the steep western approach to the Akropolis. The possible later construction of the overlapping gate system represented an improvement that met both the defensive requirements and monumental style of the Late Mycenaean period. These installations continued to provide excellent defense for the Akropolis through the Dark Age, until sometime during the Late Geometric or Early Archaic periods when the bastion and tower (at least) were damaged. From this time forward the process of transforming the Akropolis into an area of cult began. Although the walls apparently remained intact throughout the Archaic period, at its very end, perhaps during the interval between the Battles of Marathon and Salamis, they were sacrificed to other plans: the erection of the Older Parthenon and the Older Propylaia. The one activity dismantled a section of the southern wall while the other inserted a modern gate and court in place of the Mycenaean ones. ${ }^{107}$ The terraces before the wall then provided space for cult activity around the gates, ${ }^{108}$ and the Mycenaean remains lost their military significance, a process that culminated in the near total eradication of those elements not incorporated into the cult areas or monuments of the Periclean program.

\section{APPENDIX}

\section{THE ARGHAIC GISTERN AND THE NORTHWESTERN CORNER OF THE AKROPOLIS}

The northwestern area of the Akropolis is not much studied and less well understood. None of its monuments have been successfully identified through ancient testimony, and its state of preservation has relegated it to obscurity. Nonetheless it is of interest in its own right to the student of Akropolis topography and because study of its monuments can shed light on the rest of the Akropolis. In this appendix the focus of interest is on the drainage of the Akropolis, specifically the Archaic cistern and its relation to the course of the northern leg of the Mycenaean wall.

The area consists of the following monuments (Figs. 1, 10): (1) the never built northeastern hall of the Propylaia, which contains a cistern constructed in Roman times; (2) the Northwest Building, which

106 The northern terrace would have a minimum height of $c a .4 \mathrm{~m}$. above bedrock, the southern one, $c a .5 \mathrm{~m}$. (Figs. 1, 5, 7). The use of terraces as defensive architecture is well attested at Tiryns, where they were an integral part of the first and second citadels, in use down into the LH IIIB phase (Müller 1930, pp. 15-21, 25-39; Iakovides 1983, pp. 5-6).

107 Arnold Tschira discovered that the southwestern corner of the Older Parthenon foundation cut deeply into a nearly dismantled section of the Mycenaean wall (Tschira 1972, pp. 162-167, figs. 1-8, pl. 2); for the Propylaia, see Dinsmoor 1980 and Eiteljorg, in press.

108 On monuments before and around the entrance, see Judeich 1931, pp. 216-225, passim. 

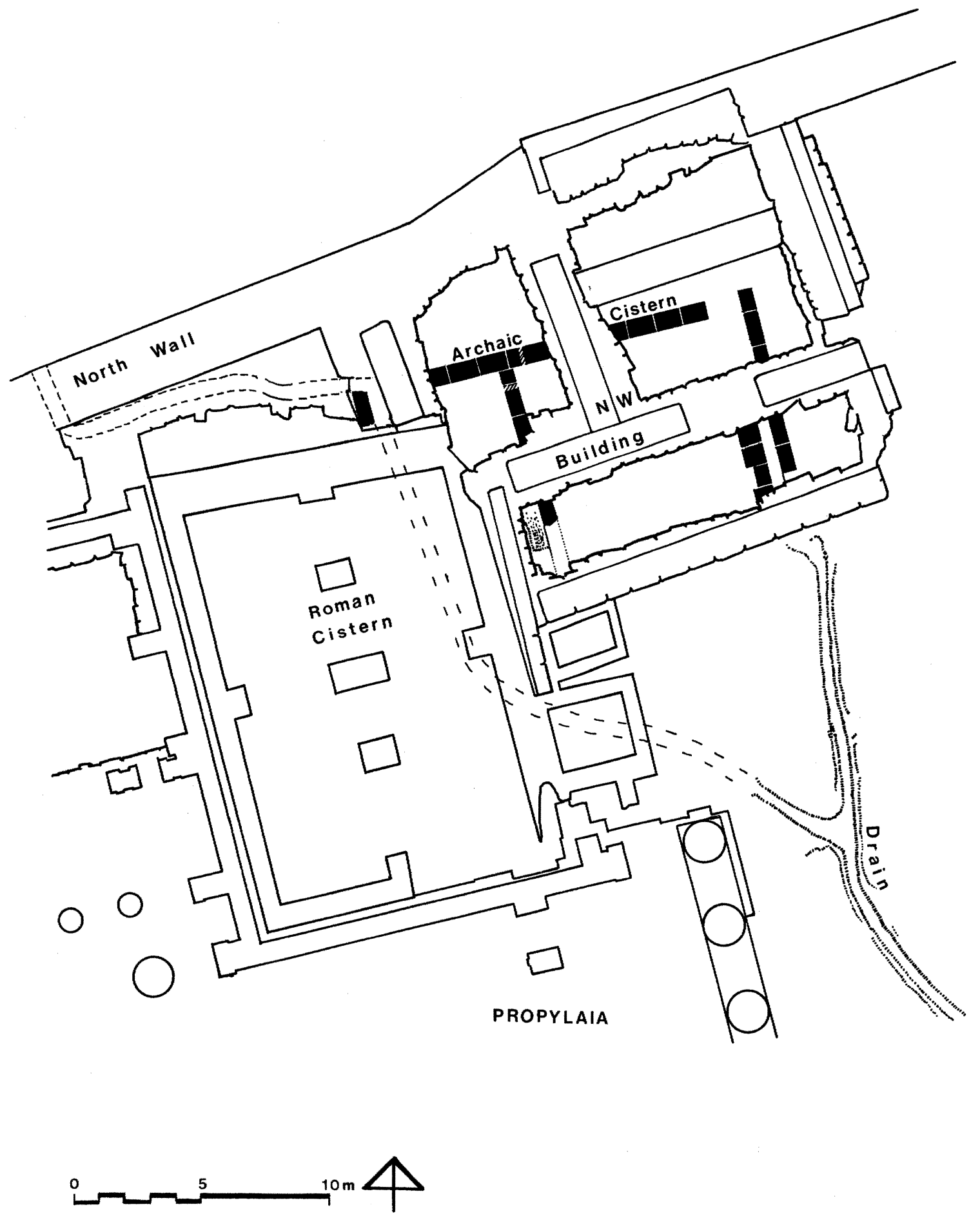

Fig. 10. Plan of the area of the Archaic cistern, adapted from Kavvadias and Kawerau 1906 (J. C. Wright) 
lies over the ruins of (3) the Archaic cistern; and (4) the short stretch of the north Akropolis wall from the Pinakotheke to just east of the Northwest Building. The basic description of these monuments is found in the report of Kavvadias and Kawerau, ${ }^{109}$ wherein the interpretation of the chronology and, in so far as it was possible, the function of the structures are considered. Only the Archaic cistern is dated before the Persian war. The Northwest Building is thought to be contemporary with the circuit wall, which according to both Kavvadias and Kawerau should be dated immediately after the Persian sack, presumably to the time of Themistokles. ${ }^{110}$ In this short study attention will be drawn to new evidence for the restoration and understanding of the history of the Archaic cistern, the drainage system leading into it, and general considerations of drainage in this area.

\section{Drainage}

The northwest corner is the natural collection point for the drainage of the Akropolis. The lowest surface in this area $(c a .+137 \mathrm{~m}$.) is directly over the caves of the North Slope; indeed, the continuous runoff of water there over the millennia has caused the hollowing out of these caves. Approaching this area is a drain cut into the rock in front of the east façade of the Propylaia. It continues northwards to the Northwest Building (Fig. 10, Pl. 77:a) and is the original drain that led to the Archaic cistern. ${ }^{11}$ This drain can be identified by a reveal cut into the bedrock on each side of the upper drain walls to receive cover slabs, now missing. A second, later channel forks to the northwest from the primary one (see p. 357 below). At the north end the original course has been marred by erosion and damage to the rock face, perhaps due partly to making the foundation bedding for the southern wall (Figs. 10, 11: wall 8) of the Northwest Building. Close examination shows that the drain ran under this wall into the Archaic cistern (Pl. 77:b).

\section{The Gistern}

The drain can be followed on the other side of this wall as it enters the cistern. As it reappears on the north side of the wall, it runs as a straight channel lined on the left side by a single preserved course of ashlar blocks of poros (Fig. 11: wall $1 \mathrm{la})^{112}$ and on the right by the continuation of the bedrock cutting until that is replaced by two blocks of poros set flush with the channel and the bedrock surface. These two blocks are part of a wall (1) which continues to the north under the massive central crosswall (9) of the Northwest Building and forms the east wall of the cistern. The area farther north is partially filled in today and cannot be inspected. It is much lower than the southern area because the bedrock drops sharply away beneath crosswall 9. Close observation of Kawerau's final published plan and of his working plan of this area shows the northernmost block of wall 1 extending slightly beyond the corner formed by the continuation of the (once) abutting east-west wall (2) of the cistern (Fig. 11; see p. 355 below). ${ }^{113}$

109 Kavvadias and Kawerau 1906, cols. 62-74; the cistern is not considered by Camp (1977) in his study of the Athenian water supply or by Glaser (1983) in his general survey of fountain houses. I thank Professor B. S. Ridgway for bringing this volume to my attention. A detailed study of this cistern by Tasos Tanoulas (1992) has recently appeared and differs in many ways from the presentation here. Although Dr. Tanoulas kindly supplied me with a draft of the article, I have not seen the plans and have not tried to reconcile the differences in our presentations of the evidence.

${ }^{110}$ Kavvadias and Kawerau 1906, cols. 26-28, 118.

111 Dörpfeld 1886, p. 333; Judeich 1931, p. 246; Stevens 1946, p. 511; Iakovides 1962, p. 118.

112 Kavvadias and Kawerau 1906, col. 68: Kawerau states that the blocks to the west of the channel come from an older construction and were first reused in their present position at a later period. The only reason for this statement, so far as I can deduce, is that the blocks are larger than those normally found in the cistern. There are, as well, no indications that the blocks could have been put in place after the cistern went out of use.

113 Kavvadias and Kawerau 1906, pl. B'; Bundgård 1974a, pl. 14. 


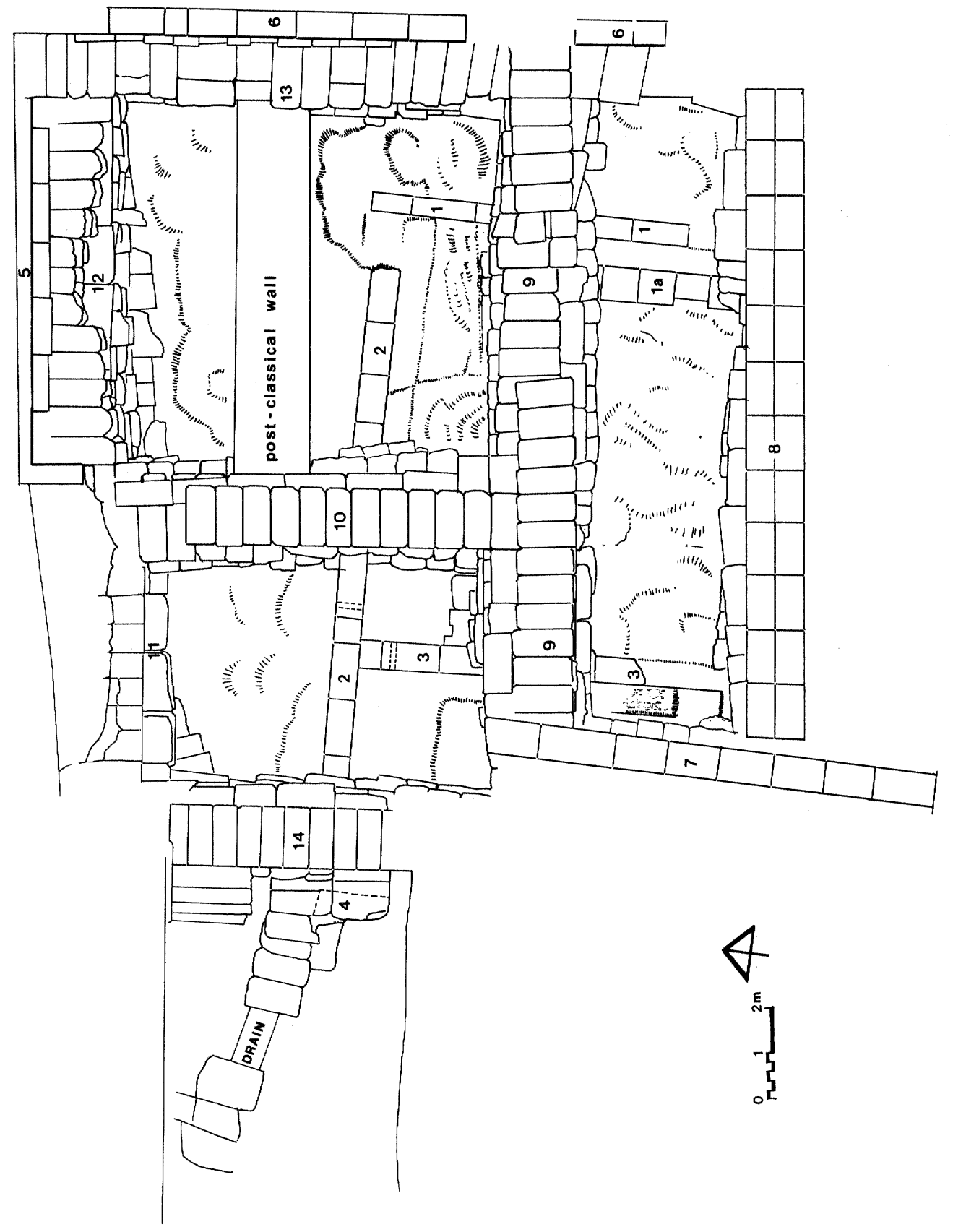

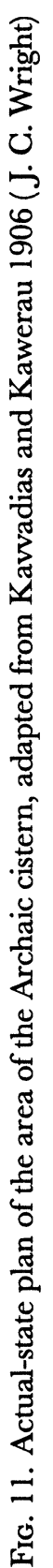


The east-west wall 2 forms the preserved north wall of the cistern. The wall can still be inspected in the northwestern room of the Northwest Building (Fig. 11; Pl. 78:a). There it is preserved two courses high and is built of poros ashlar blocks. The lowest course is set into the bedrock, which was dressed down to receive it. (In Kawerau's plan of the now buried northeastern room this cutting is shown to have been carried farther behind the inner face of the wall to form a kind of channel [Fig. 11, south of wall 2 up to wall 1]. ${ }^{114}$ ) Just east of the crosswall (3) that abuts wall 2, one of the blocks of the lowest course has a square cutting on its underside which forms a channel through the wall (Fig. 11; Pl. 78:b). At the west, wall 2 continues up to the western foundation wall of the Northwest Building, which cuts it off.

Although the westward continuation of the north wall is not preserved beyond the massive foundation of the Northwest Building, its termination can be precisely located because the western wall of the cistern is preserved by four blocks in two courses still in situ (Fig. 11: wall 4). ${ }^{115}$ These blocks now form the west side of a drain that was built in the 5th century B.C. when the construction of the Northwest Building disrupted the Archaic drainage channel (Fig. 10; see pp. 357-358 below). They are of the same poros as the other walls of the structure, are set with tight joints, and are worked with a characteristic gouging that runs across the vertical face of the blocks as a preparation for plaster (p. 354 below). The northernmost block has its north end hacked off obliquely where the 5th-century drain turned westwards. Combined with the fact that these blocks are set at a right angle to the north wall, this fact confirms that they are in their original position and establishes the northwestern corner of the cistern (Fig. 10). All the traces of the southern continuation of this wall have been obliterated by the adjacent Roman cistern.

It remains to describe the north-south crosswall 3 within the building (Fig. 11, Pls. 78:b, 79:a). This wall is preserved within the southern and northwestern chambers of the Northwest Building. At the south it consists of a single block with an irregular underside neatly fitted into the bedrock in the same manner as the blocks of the eastern wall 1. The bedrock to the west has been worked into a channel, but there are indications that this is a later reworking (Pl. 79:b). ${ }^{116}$ The possibility should be kept in mind, however, that originally a channel may have been cut here. To the north the wall continues, achieving a preserved height of four courses as it steps down the steep slope of

114 The shape of this channel can be seen in Middleton's section (1900, pl. 4: V at ' $\mathrm{H}^{\prime}$, p. 8); he thought it some kind of water channel and noted that it "was lined with fine hard waterproof stucco." Kawerau (Kavvadias and Kawerau 1906, pl. B'; cf. Bundgård 1974a, pl. 14) wondered if this channel had been purposely cut to facilitate laying the first course of masonry or had been prepared to receive a thicker wall than was finally laid. Most of the lower course of foundations for this building was carefully laid into beddings cut in the rock surface; it is therefore unlikely that the technique would have changed for the laying of this wall. Since this channel does not, apparently, continue to the west, it may be evidence that the two parts of this apparent room were separated by a wall which lies beneath the north-south crosswall 10 of the Northwest Building.

115 Kawerau did not know of these blocks and as a result recognized no preserved elements of the west wall; he presumed, however, that the wall lay much farther to the west (Kavvadias and Kawerau 1906, col. 64). In this he was followed by Iakovides (1962, p. 118, fig. 21 at 1) and Bundgård (1976, p. 38, pl. F).

116 A late (Byzantine? Turkish?) drainage system was cut through the lowest foundation courses of the east-west crosswall 9 of the Northwest Building (Pl. 80:c) and then turned to the west, where another hole was mined through the west foundation 14 of the Northwest Building, presumably to link the drain with either the Roman cistern or the Classical drain. These constructions are easily recognized today by the use of tiles and cement to help support them under the foundations and, probably, by crude cuttings in the bedrock apparently following the course of the drain (visible as the hatched bedrock corner between walls 9 and 14 in Kawerau's sketch, reproduced here as Figure 11, and in Plate 79:a). This area may have been partially excavated in 1864 (Bundgård 1974a, p. 9), which may explain why Kawerau was unable to make any stratigraphic notes when work continued in this area in 1886 (cf. Bundgård 1974a, p. 12). 
the bedrock on the other side of the central east-west foundation of the Northwest Building. This wall is built like walls 1 and 2. Like the northern wall it has a channel cut through the lowest course (Pls. 78:b, 79:a). In this channel Kawerau reported finding two marble tiles set together to form a kind of drain. ${ }^{117}$

South of the single block set into the rock at the south end of wall 3, the bedrock is dressed down as if to receive an upper course. This cutting continues to the southern wall (8) of the Northwest Building and, because no indications of this wall or of any other cistern wall can be found in the bedrock outside the building, it can be stated with near certainty that the south wall of the earlier building lay under the south wall of the Northwest Building. Indeed, Kawerau claimed that the inner face of this wall is detectable under the interior southeast corner of the Northwest Building. ${ }^{118}$ As one can see in Figure 11, some of the lowest blocks of the Northwest Building foundation appear to preserve the orientation of that earlier wall. ${ }^{119}$

Certain distinctive features of the masonry style and technique of construction employed in this Archaic cistern are important for determining its use and for recognizing its original members. Already, the careful manner of fitting the lowest course of blocks into special beddings in the bedrock had been described for the east, central, and north walls. ${ }^{120}$ All the walls are constructed of ashlar blocks of poros. The blocks of the northern wall are slightly wider than those of the other walls, but they are all of the same style. Each block is neatly cut and set next to its neighbors with very tight, straight joints. The ends are dressed with anathyrosis ( $\mathrm{Pl}$. 80:a), but there are no clamp cuttings in any of the blocks in situ nor in those lying in ruin within and built into the foundations of the Northwest Building. ${ }^{121}$ Pry holes are found in some of the upper surfaces. The upper faces of the blocks are smoothed, while the vertical ones are picked and gouged with a point (cf. Pls. 78, 80:a).

The point dressing was applied after the wall was built, since the continuous strokes cross over the joints between blocks (Pl. 78:a). The dressing was a preparation for plaster, traces of which are preserved on all visible interior faces of the walls, particularly on the east face of the abutting north-south crosswall 3 (Pl. 80:b). ${ }^{122}$ The plaster is a mixture of small pebbles, ca. $0.005 \mathrm{~m}$. in diameter, set in a sand-and-lime matrix. Today there is no trace of a fine finishing coat such as one might expect on a hydraulic installation, ${ }^{123}$ but Kawerau recorded such a surface, "a very thin yellow-colored lime surface" (my translation) over the coarse plaster. ${ }^{124}$

117 Kavvadias and Kawerau 1906, col. 68; a drawing of these tiles is shown in Bundgård 1974a, pl. 12:3. There is something very curious about this arrangement. Surely a simple channel cut through the wall would have been a more efficient drain? The tiles would, in my opinion, have easily become clogged. Were they, instead, part of a valve used to stop or slow the flow of water from one chamber to another? Or were they part of the much later reuse of this area discussed in the preceding note?

118 Kavvadias and Kawerau 1906, col. 64.

119 This relationship between pre- and post-Persian buildings occurs in several places on the Akropolis, such as the western foundation of the Pinakotheke (note 37 above).

120 Kavvadias and Kawerau 1906, col. 66.

121 Kavvadias and Kawerau 1906, col. 66.

122 Kavvadias and Kawerau 1906, where Kawerau observed this plaster, as did Middleton (1900, p. 8 [H], pl. $\mathrm{V}$ at ' $\mathrm{H}^{\prime}$ and ' $\mathrm{R}$ '). Roland Martin (1965, p. 432) notes that especially hard plasters used for hydraulic installations tended to be made partly from volcanic powders. The plasters from this cistern have not been analyzed.

123 See, however, the Fountain of Theagenes at Megara (Gruben 1964, p. 38), which has only a plastered floor while the walls were left rough. In the Southeast Fountain House of the Athenian Agora no hydraulic plaster was used in the floor or on the inner wall faces; see Thompson 1953, p. 31; Camp 1977.

124 Kavvadias and Kawerau 1906, col. 66. 
Thus, taking into consideration the evidence of the plaster, the manner of fitting the blocks into the bedrock, and the connecting channels between the chambers, it is reasonable to conclude that this structure was a hydraulic installation. Such a function might also explain the absence of clamps and dowels, since they would have been liable to rust in such a humid environment, causing spalling, although as a general rule the absence of clamps and dowels in Archaic architecture is not exceptional. ${ }^{125}$ Finally, the structure is located at the natural drainage point of the western half of the Akropolis with a major drain leading to it.

The roughly chiseled dressing of the wall faces appears on the northern face of the north wall (2). Since there is also a channel leading from the eastern chamber through that wall to the north (Fig. 11, $\mathrm{Pl} .78: \mathrm{b})$, it is highly likely that a northern chamber existed. There is, however, no trace of the northern limits of such a chamber. ${ }^{126}$ A glance at the actual-state plan (Fig. 11) shows no recorded traces whatsoever of the chamber to the north other than Kawerau's indication that the northern block of the eastern wall 1 of the cistern continued slightly beyond the line of wall 2. Also, no traces of anathyrosis on the northern face of this wall record the abutment of a return wall of this hypothetical chamber.

Kawerau, followed by Iakovides and Bundgard, argued that the preserved north chamber was set into earth which was retained at the north by the Mycenaean north wall. ${ }^{127}$ Kawerau considered this necessary since he could not believe that the narrow walls of the cistern $(0.45-0.65 \mathrm{~m}$.) could themselves have withstood the water pressure within. Of course, we have no idea how much water the cistern was designed to contain, and the scarcity of such installations known from the Archaic period means that there is little comparative material (see note 125 above). Kawerau considered the walls to form a sheathing (Verkleidungsmauern), presumably especially along the hypothesized northern trace of the Mycenaean fortification wall. Unfortunately, the Mycenaean wall is preserved neither in this area nor west of it. ${ }^{128}$ The only traces identified are a few rubble blocks on the eastern side of the modern buttress north of the northeast corner of the cistern (near $E^{\prime}$ on Fig. 1). If, as Iakovides argues, the wall continued westwards from here, then the theory of the cistern being set in fill behind the wall is reinforced. ${ }^{129}$ His argument, however, rests primarily on his understanding that the drain leading from the northwest corner of the cistern belonged to it and that its serpentine course reflected the trace of the interior line of the Mycenaean wall in this area. As is already apparent, and will be more so shortly, the evidence for the date of this channel places it after the Persian destruction and contemporaneous with the erection of the Northwest Building, thus negating its force in the argument for the course of the Mycenaean wall.

When attempting to reconstruct this cistern, there is little of substance that allows more than a general outline. Comparative evidence is scarce and uninformative. The cistern collected water channeled to the northwest corner of the Akropolis, which then flowed into the preserved northern chamber. Whether this chamber was separated from that at the south is not known because the intervening area is covered by the central east-west crosswall 9 of the Northwest Building. The

125 The question of the use of clamps and dowels in hydraulic installations is hard to answer by reference to the literature on such structures. Too few cisterns and other water-holding basins of the Archaic period (as this one on the Akropolis is to be dated, p. 357 below) are known; see the fountain at Megara (Gruben 1964), where [ and $\mathrm{H}$ clamps as well as dowels were used in the basin construction and outside walls (late 6th to first quarter of the 5th century); and the Southeast Fountain House in the Agora (Thompson 1953), where $\mathbf{Z}$ clamps are recorded in the fountain walls (second half of the 6th century B.c.).

${ }^{126}$ It is worth noticing, perhaps, that numerous blocks of the cistern can be observed today built into the northern and western foundations of the Northwest Building.

127 Kavvadias and Kawerau 1906, col. 66; Iakovides 1962, p. 119; Bundgård 1976, p. 38.

128 Iakovides 1962, pp. 117-123.

129 Iakovides 1962, pp. 118-119. 


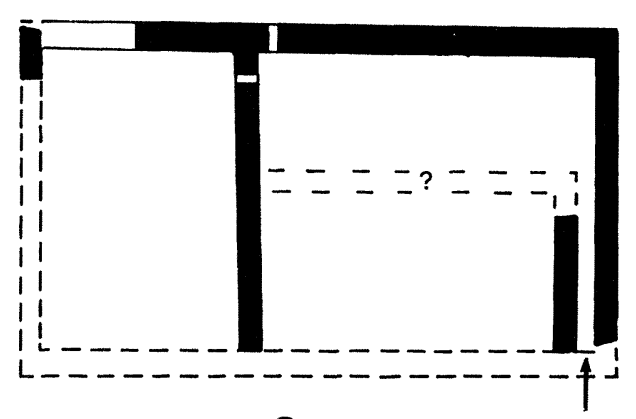

a

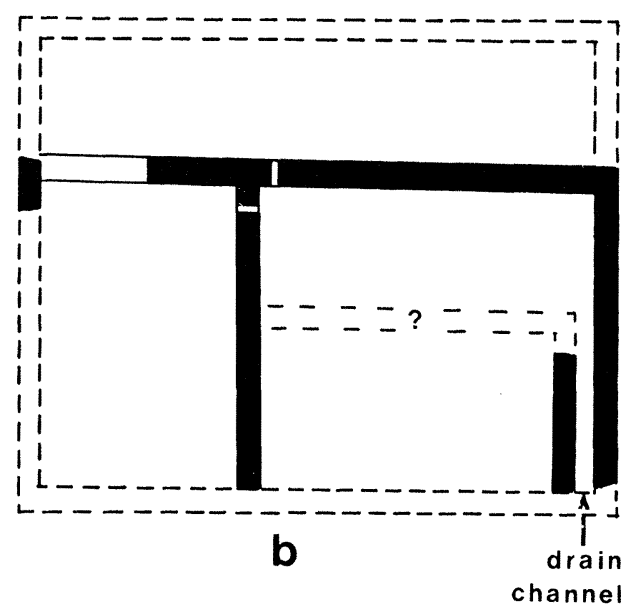

FIg. 12. Possible reconstructions of the Archaic cistern (J. C. Wright)

wall at the left of the entrance channel (Fig. 11:1a) may have returned as an east-west crosswall. Such a wall would divide the approximately eight-meter north-south width of the cistern in half, thus reducing the span. The existence of such a wall is further supported by the change in bedrock levels. To the north the bedrock falls sharply, making a separate chamber a probability. This northeastern chamber would appear not to have been subdivided. It would, however, connect with a chamber to the west via a channel cut through the base of the north-south crosswall 3 (Fig. 11, Pl. 79:a). The western chamber was probably about eight meters long from north to south, for, as we have observed, its southwestern corner lies under the south wall 8 of the Northwest Building. As restored in Figure 12, the cistern would fit into Glaser's category of "Schachtbrunnen". 130 These fountain houses are characterized by having an upper entry room with a parapet wall set before the lower cistern.

The total ensemble may have appeared as sketched in Figure 12:a or, if another narrow chamber existed at the north, as in Figure 12:b. Either of these plans could be roofed. A reasonable

130 Glaser 1983, pp. 6-11. 
reconstruction would show the southeastern chamber as an entrance room, since the bedrock is very high here. Then the northern and western chambers, which are placed beyond the drop-off of the rock, would have been reservoirs reached from the entrance chamber.

There is no archaeological evidence for the date of this building other than that provided by its destruction for the erection of the Northwest Building, which itself is no more closely datable than between the years 479 and ca. 448 B.c. ${ }^{131}$ Thus the cistern is presumably Archaic, as is agreed by all authorities. ${ }^{132}$ Iakovides would associate its construction with Herodotos' description of the Peisistratid defense of the Akropolis in the siege of 510 B.c. ${ }^{133}$ Herodotos does not record the presence of a cistern on the Akropolis but merely points out that the Peisistratids were well supplied with food and drink. ${ }^{134}$ This story may be compared with that of the Kylonian conspiracy, for which the sources relate that the trapped conspirators were starved on the Akropolis, although this version of the story has been challenged. ${ }^{135}$ Neverthless, the masonry is clearly 6 th or 5 th century in date, and the absence of clamps reinforces the notion of a 6 th-century construction.

\section{The Fifth-Gentury Drain}

As we have seen, the drain leading west from the northwestern corner of the cistern is usually considered to be a part of its arrangement. ${ }^{136}$ The drain, however, is cut through the western wall 4 of the cistern as it turns to the west (Fig. 11). Thus the contemporaneity of drain and cistern are unlikely. The exterior face of the west foundation of the Northwest Building forms the east wall of the drain. From here it turns and winds along to the west until it disappears under the Akropolis wall. ${ }^{137}$

Unlike the rock-cut drain leading into the cistern, this drain is lined and covered with stone blocks, some reused from earlier structures ${ }^{138}$ but most of the same chalky, soft poros employed in the foundations of the Northwest Building. Thus the drain is probably contemporary with that building. This sequence makes sense when the topography of the area is considered in relation to the buildings. When the Archaic cistern was functioning, the runoff from the Akropolis was collected and controlled. At the time of the destruction of the cistern the drainage of the Akropolis was uncontrolled; water ran freely over the edge and into the cave sanctuaries below. This situation was remedied when the Northwest Building was constructed. The drain was diverted from its original course by a new channel cut into the rock in front of the proposed building (Fig. 10: dotted lines; Pl. 80:c) and then turned north to run along the west side of the building. ${ }^{139}$ Its course continued to within a few meters

131 Kavvadias and Kawerau 1906, col. 64.

132 Dörpfeld 1886, p. 333; Judeich 1931, p. 246; Kavvadias and Kawerau 1906, col. 64; Iakovides 1962 , pp. 118-119; Bundgård 1976, p. 32.

133 Iakovides 1962, note 235; Herodotos 5.65; Iakovides maintains that the cistern could not be much earlier since, according to Thucydides (1.126.9), Kylon a century earlier had surrendered from the Akropolis for lack of water.

134 I thank Professor Camp for pointing this out to me.

135 Thucydides 1.126; see, however, Lang 1967, pp. 243-249.

136 Iakovides 1962, pp. 118-119, contra Kavvadias and Kawerau 1906, col. 68. Bundgård (1976) is of the opinion that the drain was installed directly after the destruction of the cistern in 479 B.c.

137 Kavvadias and Kawerau (1906, col. 68) traced the exit of the drain from the Akropolis wall (pl. $\mathrm{B}^{\prime}$ ) and associated its blocking with the late Turkish walling of the circuit.

138 Kavvadias and Kawerau 1906, col. 68.

139 Contra, Bundgård 1976, p. 38 (see note 144 below). Why the drain ran north along the west side of the Northwest Building and not diagonally, directly over to its outlet over the cliff, is not clear. The complete obliteration of earlier remains in the area by the Roman cistern prohibits investigation of this problem. Either there existed a structure or cult area that prevented the drain from cutting through this place or there may have 
of the edge of the Akropolis and then turned west again until it could be directed over the north face, on the west side of the cave sanctuaries. ${ }^{140}$

The effluent of the drain is now blocked. Patchwork modern masonry over the north circuit wall between the Northwest Building and the rear of the Pinakotheke covers the drain. Kawerau, however, recorded and described its course as it continues under the wall to empty over the cliff. Although one cannot today observe it in action, ${ }^{141}$ it is obvious from Kawerau's plan that the drain did not entirely direct the outflow away from the cave area. The mouth of the drain was situated over the westernmost side of the roof of the westernmost cave. ${ }^{142}$ Either other provision, no longer recognizable, to direct the water beyond the cave had originally been made, or the occasional flow of water into the west end of the open-air sanctuaries caused no alarm. In any event, the primary function of the drain, to keep water out of the deep foundations of the Northwest Building, was achieved.

The masonry forming the wall presently covering the drain is a mixture of repairs and additions from classical through modern times. Most of the exterior face is modern, the work of Kaftanzoglou, ${ }^{143}$ but the lowest courses are ashlar and would seem to be part of the 5th-century wall. The interior face shows ashlar masonry of the same poros and is similar in workmanship to that of the foundations of the Northwest Building. ${ }^{144}$ The coursing of this face also corresponds to that of the building foundations. Thus, they are likely contemporary in construction.

In summary, we have the following evidence for this area. First, there is nothing left to indicate the course of the northern leg of the Mycenaean wall. The earliest construction preserved today is the cistern fed by runoff water channeled to it. This structure stepped down over the steeply falling bedrock and consisted of two or three chambers made of poros ashlar blocks covered with plaster. It was abandoned after the Persian sack of the Akropolis in 480 B.c. Built above it in the following years was the Northwest Building, a formal structure of two back rooms and a front porch which was erected on heavy foundations that raised the northern part of the building to ground level. This structure disrupted the course of the Archaic drains and forced a redirecting of the drainage. A new channel was cut into the bedrock to take the water around the western side of the Northwest Building into a slab-covered and stone-built drain that snaked farther westward to an effluent in the north Akropolis wall.

existed an earlier overflow drain from the cistern which was simply linked up with the new drain. Kawerau (1906, col. 62) believed that the branch drain was first cut into the rock for the great Roman cistern built into the northeast wing of the Propylaia. If this were the case, then there would have existed no drainage for this area from the time of the Persian sack to Roman times and, especially, no provision to drain away seepage around the deep foundations of the Northwest Building. It is more likely that the Roman cistern merely utilized an existing drain channel.

140 Of course, it is possible that the course of this drain was originally cut out to take runoff from the Archaic cistern. As Kawerau observed (1906, p. 68), there are no traces of such an arrangement.

${ }^{141}$ Instead, new drains have been cut through the north wall at intervals; one is visible north of the Archaic cistern.

142 Kavvadias and Kawerau 1906, pl. B'.

143 Kavvadias and Kawerau 1906, col. 17.

144 Bundgård (1976, pp. 38-39 and pl. F, at q) sees the foot of the Northwest Building (the broad podium at the northwest corner foundation) as overlapping the water channel and in consequence assumes it to be a later construction. In fact, the blocks do not overlie the channel, although they are based at the same level as the blocks covering the channel, and they are all of the same material and workmanship and set in continuous or matching courses. Thus, again, the drain channel is necessary only because the Northwest Building foundations were to be constructed. Kawerau did not quite draw this conclusion: compare his last sentence about the "Wasserkanal" with the following first sentence about the "Nordwestbau" (1906, col. 68). 


\section{BIBLIOGRAPHY}

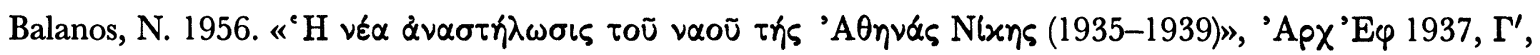
[1956], pp. 776-807

Beulé, C. E. 1862. L'acropole d'Athènes, Paris

Blegen, E. 1936. "News Items from Athens," A7A 40, pp. 145-153

- 1940. "News Items from Athens," $A 7 A 44$, pp. 537-542

Bohn, R. 1880. "Bericht über die Ausgrabungen auf der Akropolis zu Athen im Frühjahr 1880," AM 5, pp. 311-312

1882. Die Propylaeen der Akropolis zu Athen, Berlin

Bundgård, J. A. 1957. Mnesicles, Copenhagen

- 1974a. The Excavation of the Athenian Acropolis, 1882-1890, Copenhagen

- 1974b. "Le Sujet de IG $\mathrm{I}^{2}$ 24," Mélanges helléniques offert d G. Daux, Paris, pp. 43-49

1976. Parthenon and the Mycenaean City on the Heights, Copenhagen

Camp, J. McK. 1977. "The Water Supply of Ancient Athens from 3000 to 86 B.C." (diss. University of Michigan 1977)

Charitonides, S. 1960. "Hieron Pyles," $A M$ 75, pp. 1-3

Daux, G. 1956. "Chronique des fouilles et découvertes archéologiques en Grèce," BCH 80, pp. 219-360

Dinsmoor, W. B. 1931. The Archons of Athens in the Hellenistic Age, Cambridge, Mass.

$\longrightarrow \rightarrow$. 1947. "The Hekatompedon on the Athenian Acropolis," A7A 51, pp. 109-151

Dinsmoor, W. B., Jr. 1980. The Propylaia to the Athenian Akropolis, I, The Predecessors, Princeton

Dörpfeld, W. 1885. "Die Propyläen der Akropolis von Athen," AM 10, pp. 131-144

. 1886. "Miscellen: Ausgrabungen," AM 11, pp. 328-333

Eiteljorg, H. 1975. "New Finds Concerning the Entrance to the Athenian Acropolis," AAA 8, pp. 94-95

- In press. The Entrance to the Athenian Akropolis before Mnesikles (AIA Monographs n.s. 1), Boston

Glaser, F. 1983. Antike Brunnenbauten (Kpł́val) in Griechenland (Österreichische Akademie der Wissenschaften, philosophisch-historische Klasse Denkschriften 161), Vienna

Gruben, G. 1965. "Das Quellhaus von Megara," $\Delta \varepsilon \lambda \tau$ 1964, A', [1965], pp. 37-41

Hill, I. T. 1953. The Ancient City of Athens, New York

Hope Simpson, R., and O. T. P. K. Dickinson. 1979. A Gazetteer of Aegean Civilisation in the Bronze Age, I, The Mainland and the Islands (SIMA 52), Göteborg

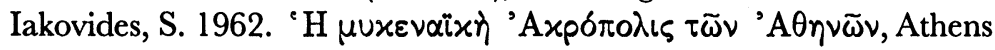

- 1983. Late Helladic Citadels on the Mainland of Greece (Monumenta graeca et romana 4), H. F. Mussche, ed., Leiden

Judeich, W. 1931. Topographie von Athen, rev. ed., Munich

Karo, G. 1936. "Archäologische Funde in Griechenland," $A A$ [ $7 d I$ 51], cols. 94-214

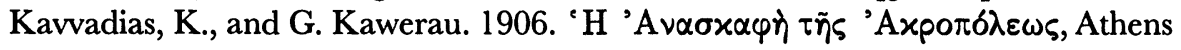

Kilian, K. 1978. "Ausgrabungen in Tiryns, 1976," $A A$ [JdI 93], pp. 449-470

LaFollette, L. 1986. "The Chalkotheke on the Athenian Akropolis," Hesperia 55, pp. 75-87

$\rightarrow$ Lang, M. 1967. "Kylonian Conspiracy," CP 62, pp. 243-249

Lemerle, P. 1936. "Chronique des fouilles et découvertes archéologiques en Grèce," BCH 60, pp. 452-489

- 1937. "Chronique des fouilles et découvertes archéologiques en Grèce," $B C H$ 61, pp. 441-476

- 1938. "Chronique des fouilles et découvertes archéologiques en Grèce," BCH 62, pp. 443-483

- 1939. "Chronique des fouilles et découvertes archéologiques en Grèce," BCH 63, pp. 285-324

Mark, I. S. 1993. The Sanctuary of Athena Nike in Athens: Architectural Stages and Chronology (Hesperia Supplement 26),

Princeton

Martin, R. 1965. Manuel d'architecture grecque, I, Matériaux et Techniques, Paris

Michaelis, A. D. 1876. "Bemerkungen zur Periegese der Akropolis von Athen," AM 1, 1876, pp. 275-307

Middleton, J. 1990. Plans and Drawings of Athenian Buildings (Society for the Promotion of Hellenic Studies,

Supplementary Paper 3), London

Müller, K. 1930. Tiryns, III, Die Architektur der Burg und des Palastes, Augsburg 


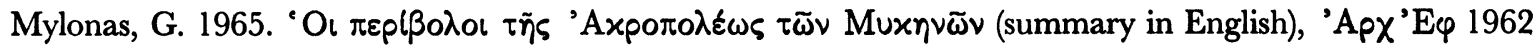
[1965], pp. 167-199

-1966. Mycenae and the Mycenaean Age, Princeton

Naumann, R. 1971. Architektur Kleinasiens, Berlin

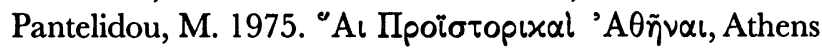

Picard, C. 1929. L'acropole, Paris

Riemann, H. 1937. "Archäologische Funde in Griechenland," $A A$ [ $7 d I$ 52], cols. 86-184

$\rightarrow$ Rhodes, R., and J. Dobbins. 1979. "The Sanctuary of Artemis Brauronia on the Athenian Akropolis," Hesperia 48, pp. 325-341

Ross, L. 1861. Archäologische Aufsätze, Leipzig

Ross, L., E. Schaubert, and C. Hansen. 1839. Der Temple der Nike Apteros, Berlin

$\rightarrow$ Stevens, G. P. 1946. "Architectural Studies concerning the Acropolis of Athens," Hesperia 15, pp. 73-106

Tanoulas, T. 1987. "The Propylaea of the Acropolis at Athens Since the Seventeenth Century," $7 d I$ 102, pp. $413-483$

. 1992. "The Pre-Mnesiclean Cistern on the Athenian Acropolis," AM 107, pp. 129-160

$\rightarrow$ Thompson, H. A. 1953. "Excavations in the Athenian Agora," Hesperia 22, pp. 25-56

$\longrightarrow \rightarrow-$ 1978. Review of Bundgård 1976, AJA 82, pp. 256-258

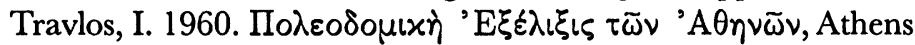

- 1971. Pictorial Dictionary of Ancient Athens, New York

Tschira, A. 1972. "Untersuchungen im Süden des Parthenon," $7 d I$ 87, pp. 158-231

Vanderpool, E. 1974. "The Date of the Pre-Persian City-Wall of Athens," in $\Phi O P O \Sigma$, D. W. Bradeen and M. F. McGregor, eds., Locust Valley, New York, pp. 156-160

Wace, A. J. B. 1949. Mycenae. An Archaeological History and Guide, Princeton

Walter, O. 1940. "Archäologische Funde in Griechenland," $A A$ [ $7 d I$ 55], cols. 121-308

$\rightarrow$ Weller, C. H. 1904. "The Pre-Periclean Propylon of the Acropolis of Athens," A7A 8, pp. 35-70

Welter, G. 1939. "Zum Nikepyrgos," $A A$ [JdI 54], 1939, cols. 1-9

Wolters, P. 1889. "Miscellen," $A M$ 14, 1889, pp. 121-122

Wright, J. 1978. "Mycenaean Masonry Practices and Elements of Construction” (diss. Bryn Mawr College 1978)

- 1980. "Mycenaean Palatial Terraces," AM 95, pp. 59-86

. Forthcoming. "The Spatial Configuration of Belief: The Archaeology of Mycenaean Religion," in Placing the Gods, Sanctuaries and the Sacred Landscape of Ancient Greece, R. Osborne and S. Alcock, eds., Oxford

Bryn Mawr College

JAMES C. WRIGHT

Department of Classical and Near Eastern Archaeology

Bryn Mawr, PA 19010-2899 


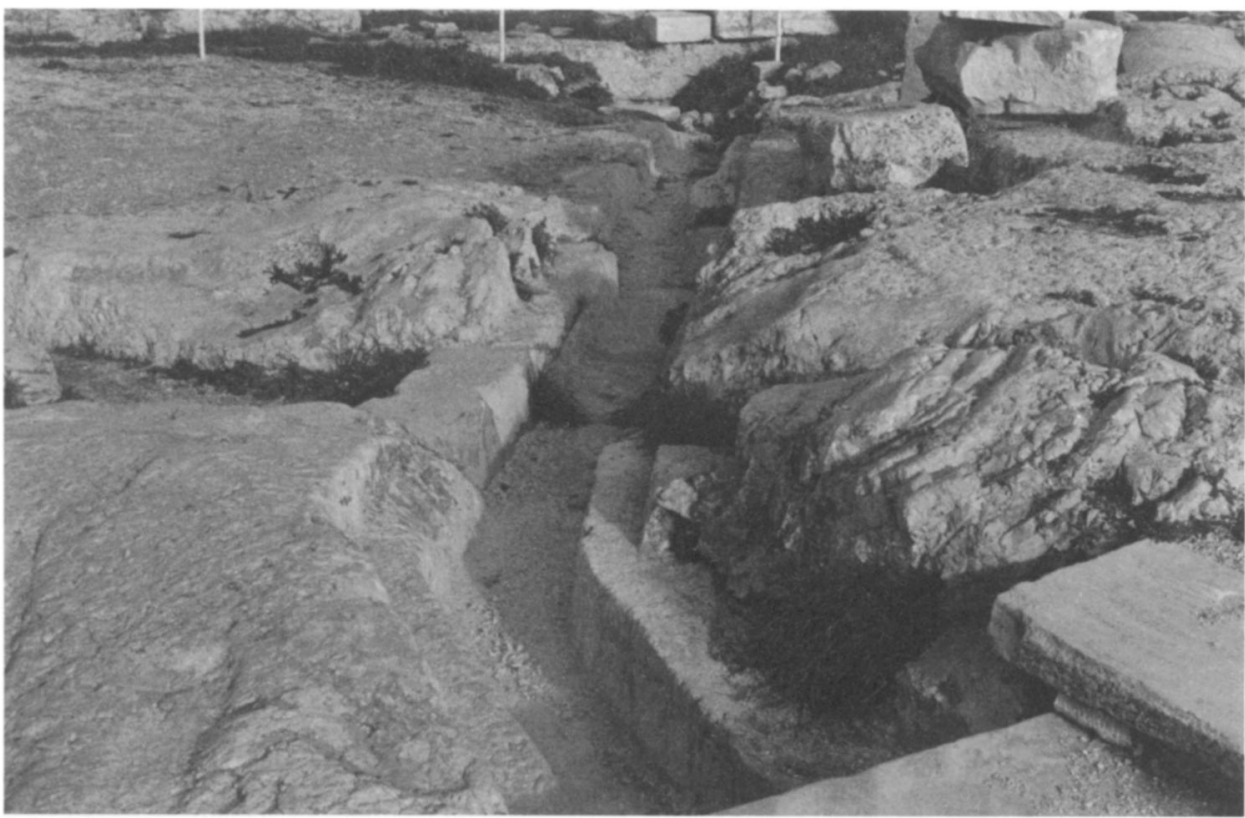

a. Drain cutting leading from the east porch of the Propylaia towards the Archaic cistern. From south

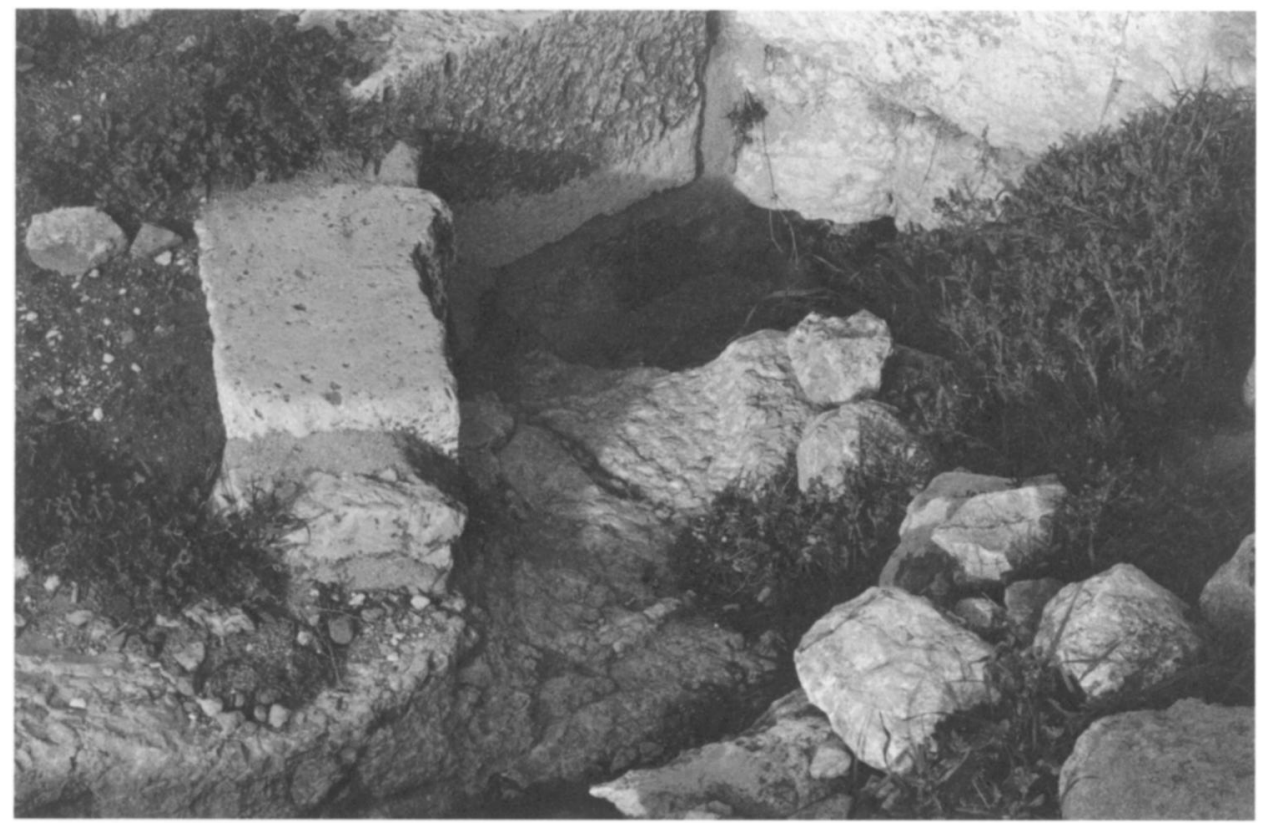

b. Drain leading into the Archaic cistern, north face 
PLATE 78

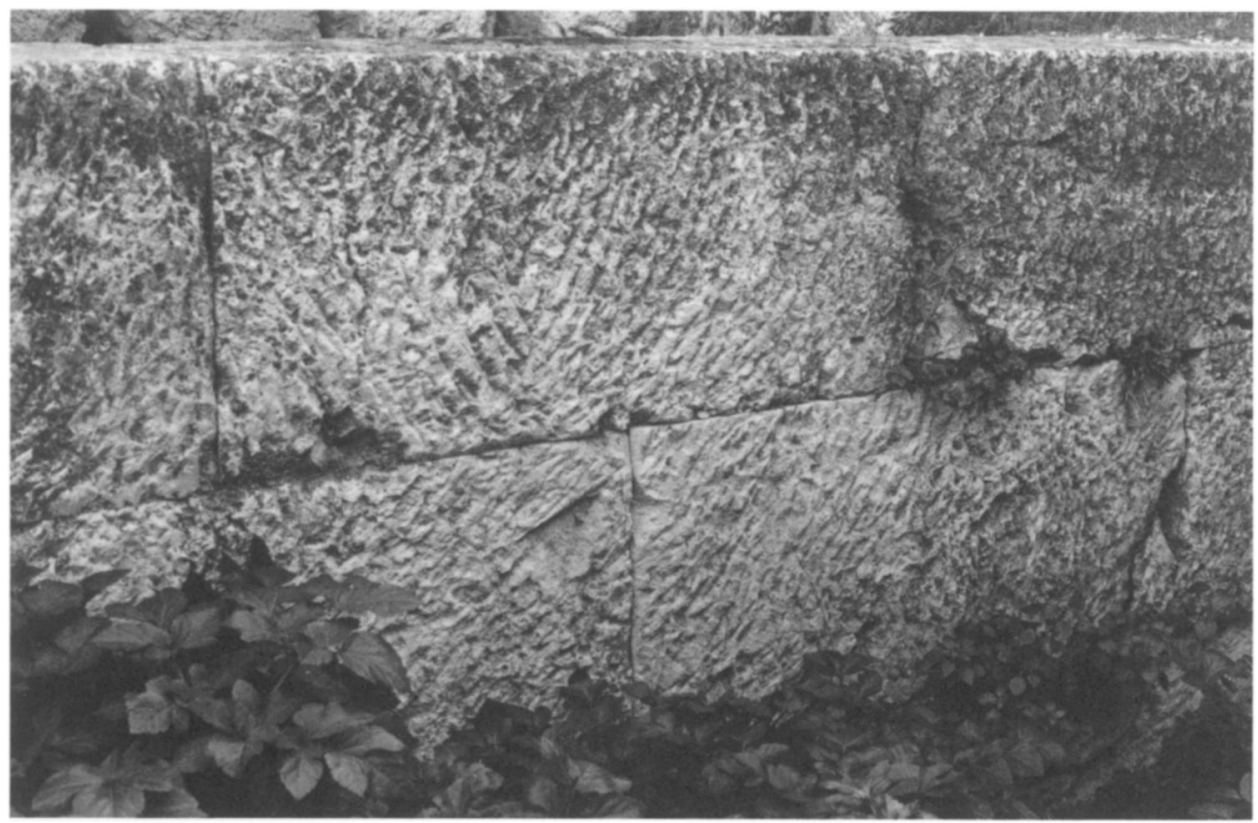

a. East-west wall 2 of the Archaic cistern, north face

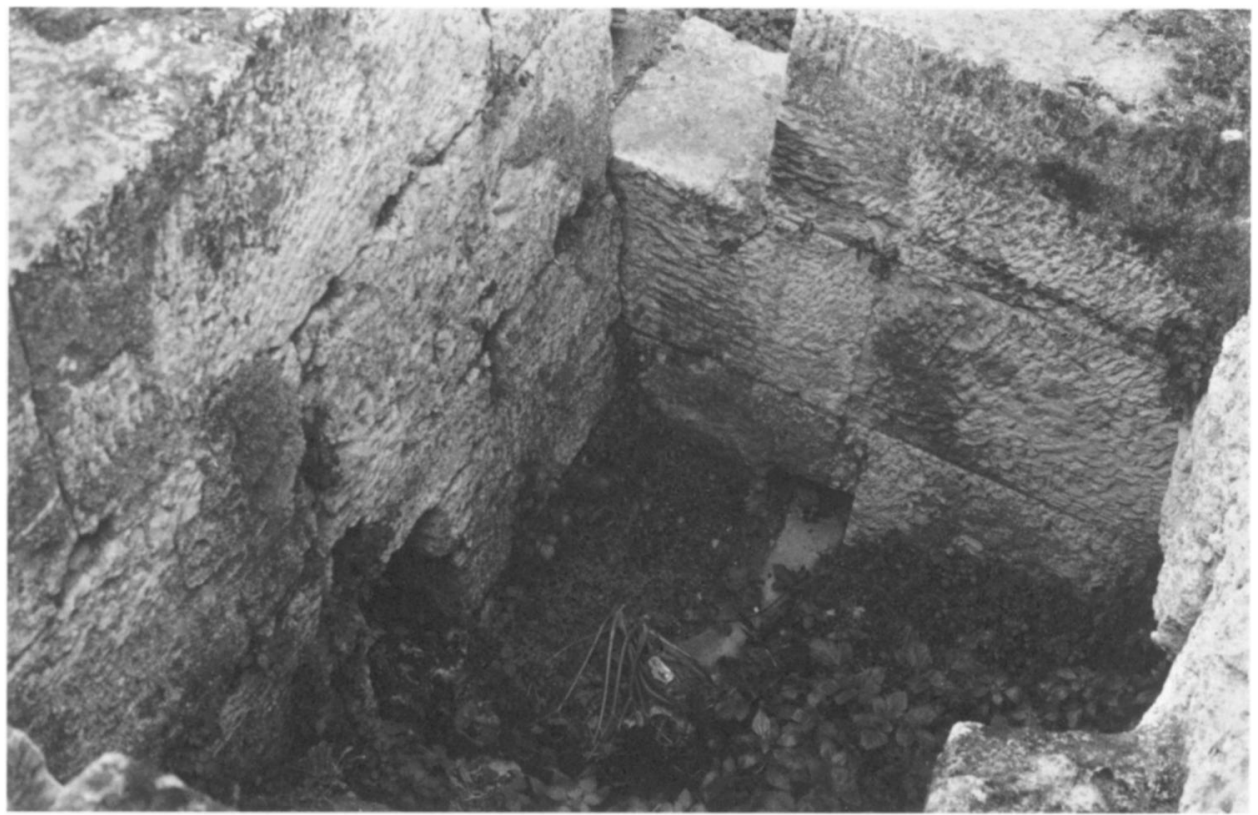

b. Drain channel in north wall 2 (right) and crosswall 3 of the Archaic cistern. From south 
PLATE 79

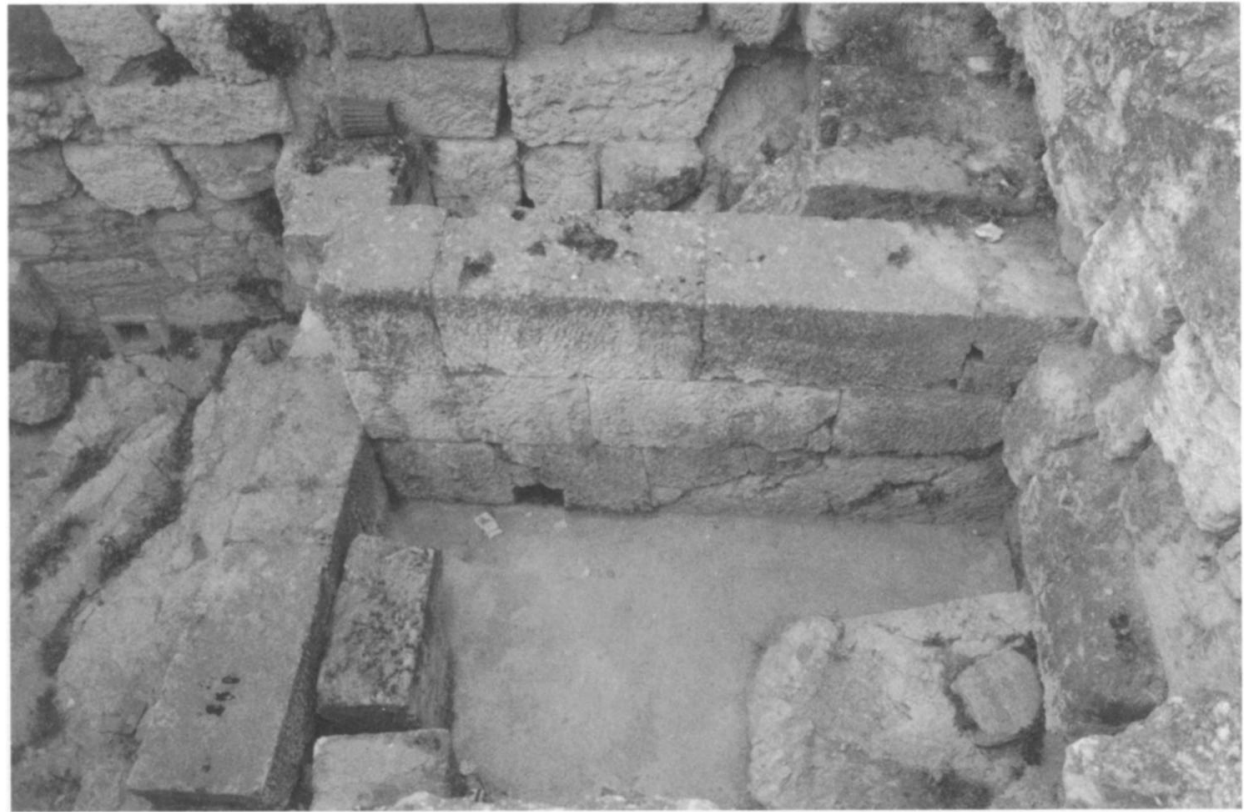

a. North-south crosswall 3 of the Archaic cistern. From west

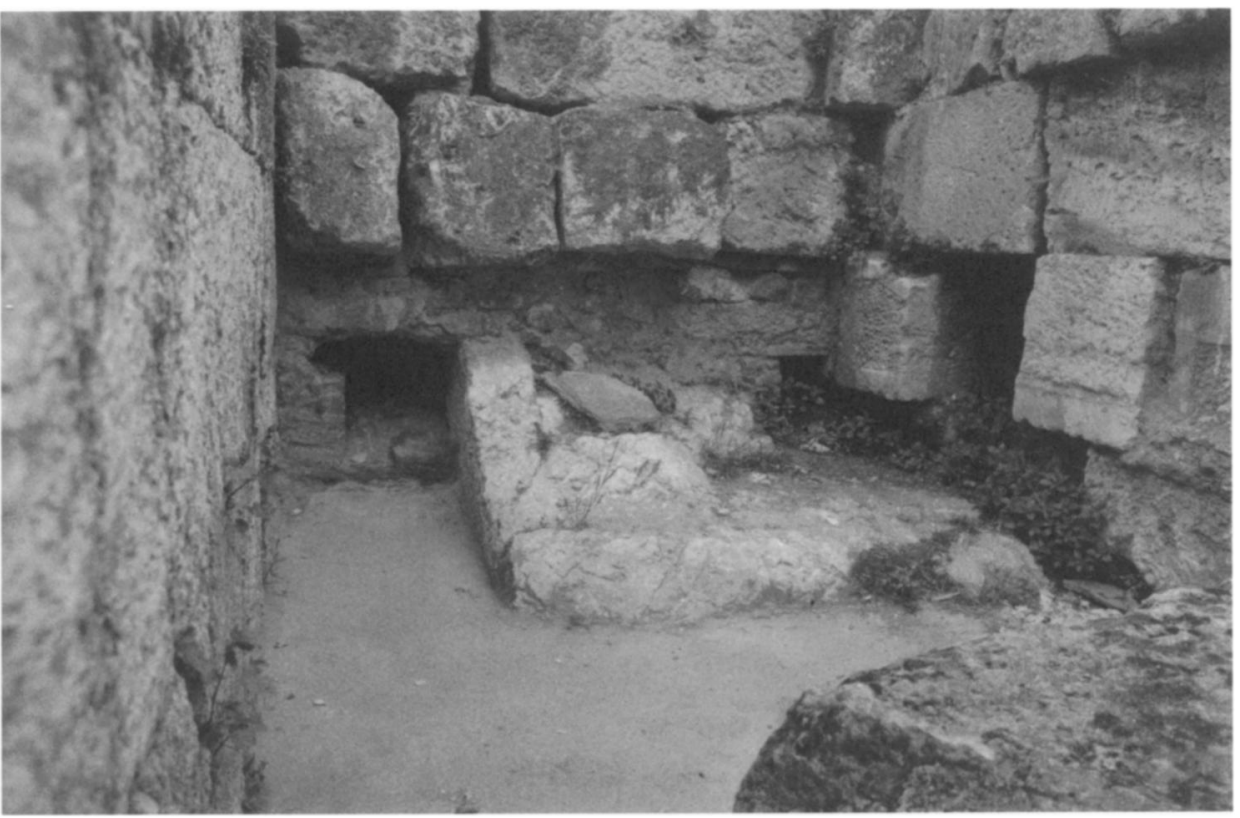

b. Later drains and worked bedrock in the northwest room of the Archaic cistern. From north 

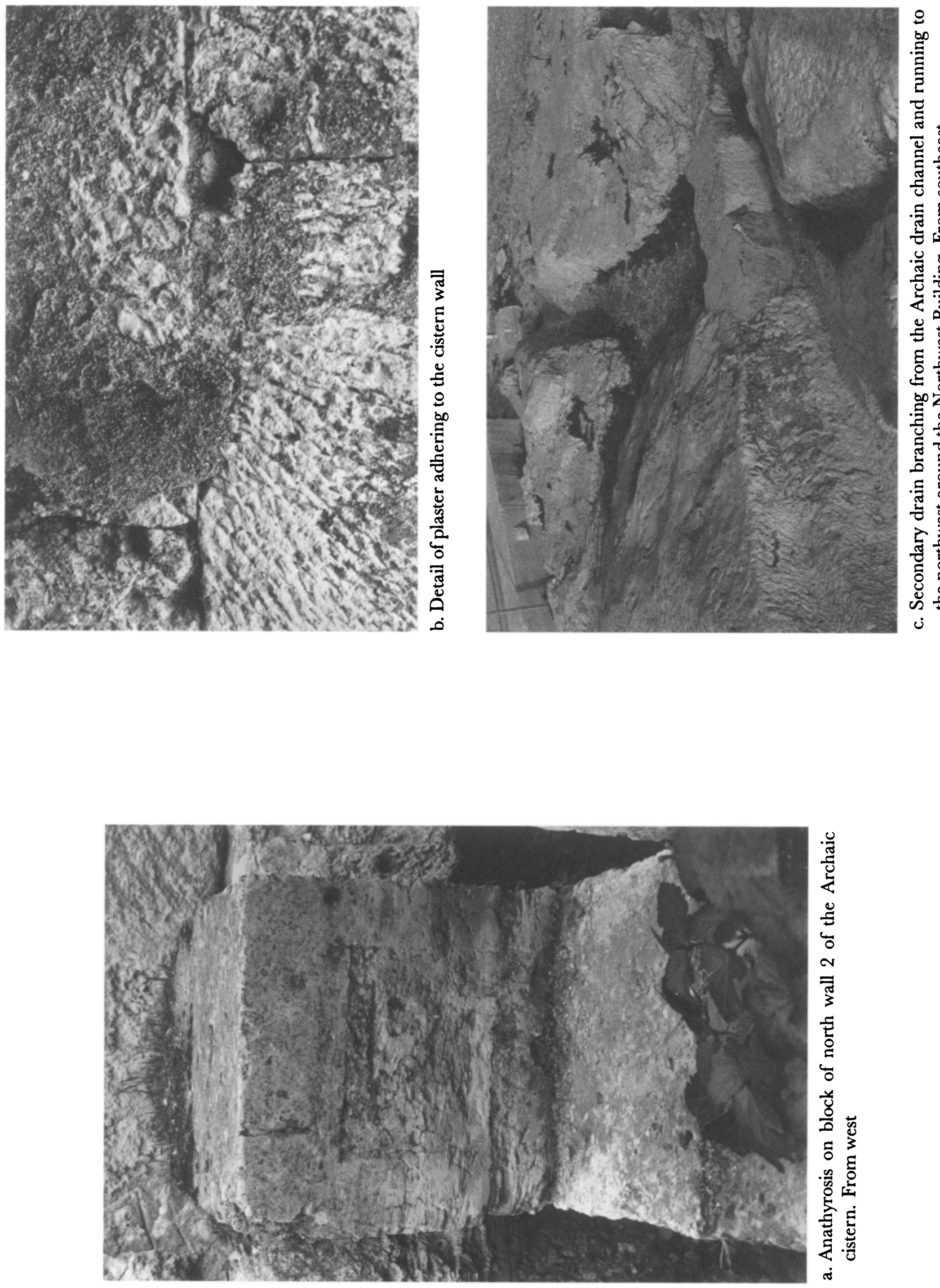